\title{
Acidic Character of Metal-Loaded Amorphous and Crystalline Silica-Aluminas Determined by XPS and Adsorption Calorimetry
}

\author{
Aline Auroux \\ Institut de Recherches sur la Catalyse, CNRS, 2 Av. A. Einstein, F-69626 Villeurbanne Cedex, France \\ Antonella Gervasini* \\ Dipartimento di Chimica Fisica ed Elettrochimica, Università degli Studi di Milano, Via C. Golgi 19, \\ I-20133 Milano, Italy \\ Claude Guimon \\ Laboratoire de Physico-Chimie Moléculaire, UMR (CNRS) 5624, Université de Pau et des Pays de l'Adour, \\ Hélioparc, 2 Av. Pdt-Angot, F-64053 Pau Cedex 9, France
}

Received: January 21, 1999; In Final Form: June 10, 1999

\begin{abstract}
The XPS technique in combination with microcalorimetry was used to picture the acid character of metal ion loaded zeolite and silica-alumina samples. $\mathrm{Co}, \mathrm{Cu}$, and $\mathrm{Ni}$ ions were loaded on ZSM-5 and $\mathrm{SiO}_{2}-\mathrm{Al}_{2} \mathrm{O}_{3}$ (about $1 \mathrm{mmol} / \mathrm{g}$ ) by three different procedures: ion exchange, impregnation, and solid-state ion-exchange. The samples prepared by ion exchange of the two matrixes presented high values of the $2 \mathrm{p}^{3 / 2}$ XPS bands of the metal ions, indicating the occurrence of charge transfer from the ions to the support matrix. This permitted the stabilization of the metal phases as isolated ions rather than as oxide clusters. Microcalorimetric experiments of ammonia adsorption were performed in order to determine the number, strength (i.e., adsorption enthalpy), and strength distribution of the acid sites on the samples and on the relevant matrixes. The N 1s XPS lines of ammonia adsorbed on the surfaces were decomposed into two component peaks, assigned to Brönsted (average value of BE, $402.2 \mathrm{eV}$ ) and Lewis (average value of BE, $400.4 \mathrm{eV}$ ) acid sites. The relative intensities of the two peak components were measured for the quantitative determination of Brönsted and Lewis acid site concentrations. Coupling the information from adsorption calorimetry and XPS spectroscopy of N 1s adsorbed lines, the absolute numbers of Brönsted and Lewis acid sites on each sample were determined. The two support matrixes were protonic acids (65 and 60\% of Brönsted acid sites for ZSM-5 and $\mathrm{SiO}_{2}-\mathrm{Al}_{2} \mathrm{O}_{3}$, respectively), and the acidity of ZSM-5 was greater than that of $\mathrm{SiO}_{2}-\mathrm{Al}_{2} \mathrm{O}_{3}$ considering both the number of total acid sites and the acid strength. The presence of metal ions deposited on the two matrixes deeply changed the respective proportions of Brönsted and Lewis sites. A huge increase in the Lewis acid site population of the ZSM-5-based samples $(70,85$, and $90 \%$ of Lewis sites for the samples containing $\mathrm{Co}, \mathrm{Cu}$, and $\mathrm{Ni}$, respectively) and of the $\mathrm{SiO}_{2}-\mathrm{Al}_{2} \mathrm{O}_{3}$-based samples prepared by ion exchange $(55,60$, and $70 \%$ of Lewis sites for the samples containing $\mathrm{Co}, \mathrm{Cu}$, and $\mathrm{Ni}$, respectively) was observed.
\end{abstract}

\section{Introduction}

The surface acidity of catalytic solids, wherein Brönsted and/ or Lewis sites, ${ }^{1}$ determines their application in many hydrocarbon transformation reactions of remarkable importance for petrochemistry. ${ }^{2-5}$ The acidic character of solids can be successfully studied by using approaches based on titration methods in solution with Hammett indicators and on gas-phase adsorption methods with series of chemisorbed electron donor molecules (ammonia and pyridine among others). ${ }^{6}$ Various physicochemical techniques ${ }^{7-10}$ have been employed to study the acidity of catalytic solids, that is, the nature and number of acid sites. In addition, acid strength and strength distribution are important aspects for a complete knowledge of the acidity of solids. The most important and widespread used techniques are temperatureprogrammed desorption ${ }^{11-18}$ and infrared spectroscopy. ${ }^{8,13,19-26}$ However, an ideal technique able to furnish an exhaustive

* Corresponding author: Phone: +39 0226603 293. Fax: +3902 70638129. E-mail: antonella.gervasini@unimi.it. knowledge of the acid character of solids is not known. A combination of techniques can provide a comprehensive picture of the solid acidity in terms of their nature (Brönsted or Lewis sites), number, and ultimately their strength and strength distribution. ${ }^{27-33}$

Adsorption microcalorimetry permits an accurate determination of the strength and strength distribution of surface acid sites based on heat of adsorption of suitable probe molecules and the differential heat vs coverage curve. ${ }^{9,34-37}$ However, microcalorimetry cannot generally distinguish between Brönsted and Lewis acid sites. The analysis of XPS data of adsorbed nitrogencontaining base probe molecules on solid surface can provide the identification and the quantitative determination of Brönsted and Lewis site concentration. ${ }^{38-40}$ Large shifts in the observed binding energy of the $\mathrm{N} 1 \mathrm{~s}$ core-level line of adsorbed $\mathrm{N}$-probe molecules are used.

The contribution of adsorption calorimetry to the problem of the acidity of catalysts of various type, zeolitic as well as 
oxidic materials, has been proven by various articles which have appeared in the literature in the past decade. ${ }^{41-54}$ Auroux $^{55}$ recently focused on the usefulness of microcalorimetry for the characterization of acid catalysts with relationship to reactivity. As concerns XPS, more limited work has been done. Kaliaguine ${ }^{39,40,56,57}$ utilized XPS for the study of the acid character of various zeolites. Recently, Johansson and Klier ${ }^{58}$ proposed highresolution X-ray photoelectron spectroscopy (HR-XPS) as a tool for the characterization of acid catalysts; examples for sulfonic polymeric resins, sulfate-doped zirconia, and various zeolites were presented.

In this perspective, the present work explores the possible applicability of the XPS technique in combination with microcalorimetry to picture the acidity feature of metal ion-loaded zeolite and silica-alumina catalysts. It is well-known ${ }^{8,9,55}$ that the acidity of zeolites is influenced by the $\mathrm{Si} / \mathrm{Al}$ ratio, the synthesis method, the nature of cationic exchange, besides the isomorphous substitution of the tetrahedral atoms and the additives incorporated. In parallel, the acidity of amorphous silica-aluminas is influenced by the alumina content, the synthesis method, and the additives incorporated. When crystalline or amorphous silica-aluminas are loaded with different metal ions, one expects, as a general trend, a decrease of Brönsted acidity and an increase of Lewis acidity (due to the countercation presence) compared with the parent material. ${ }^{45,46,55,59}$ The extent of the phenomenon can or cannot be quantitative as a function of the amount of metal loaded. In addition, the acid strength of the modified solid can be higher or lower than that of the parent acid depending on the Lewis acid strength of the countercation and on the distribution of the different types of acid sites formed. In this way, a protonic acid can be transformed in part or completely into a Lewis one, leading to important effects on its catalytic performances. ${ }^{8,55}$

Metal-exchanged zeolites as well as other amorphous or crystalline structures have recently received great attention due to their activity and selectivity toward the decomposition and reduction with hydrocarbons (SCR process) of nitrogen oxides $\left(\mathrm{NO}_{x}\right)$, the hazardous air pollutants formed as byproducts during high-temperature combustion processes $.^{60-67} \mathrm{Cu}-\mathrm{ZSM}-5$ and related materials ${ }^{68-70}$ could provide a solution for SCR catalysts due to its good activity and selectivity in a highly oxidizing atmosphere, but problems of deactivation (hydrothermal or poisoning by $\mathrm{SO}_{2}$ ) have to be overcome. The acid character of these modified zeolites is not well-known, and questions arise about the possible role of the various kinds of acid sites in the transformation of $\mathrm{NO}_{x}$.

A thorough study of the nature, number, strength, and strength distribution of the acid sites of metal-modified crystalline and amorphous silica-aluminas (Co-, Cu-, and Ni-loaded ZSM-5 and $\mathrm{SiO}_{2}-\mathrm{Al}_{2} \mathrm{O}_{3}$ matrixes) coupling microcalorimetry and photoelectron spectroscopy techniques is presented. The influence of the type of metal ion and of the method of preparation (ion exchange, impregnation, and solid-state ion-exchange) on the acid character of the modified silica-aluminas has been investigated.

\section{Experimental Section}

Preparation of Samples. The amorphous and crystalline samples were prepared by deposition of $\mathrm{Co}, \mathrm{Cu}$, and $\mathrm{Ni}$ ions on $\mathrm{SiO}_{2}-\mathrm{Al}_{2} \mathrm{O}_{3}(\mathrm{SA})$ and ZSM-5 (Z) matrixes. SA with an alumina content of 13.5 wt $\%$ from Akzo Chemie (code LA300-5P) and ZSM-5 with an $\mathrm{Al}_{2} \mathrm{O}_{3}$ content of 2.9 wt $\%$ were used in their $\mathrm{H}^{+}$form.
Three different methods of preparation were used: ionexchange (E), incipient wetness impregnation (I), and mechanical mixing, that is, solid-state ion-exchange (M).

Conventional exchange procedures (E) using dilute aqueous solutions of cobalt, copper, and nickel acetates (Fluka, > 99\% purity) were performed. The concentrations of the salt solutions used were $\left[\mathrm{Co}^{2+}\right]=0.68 \mathrm{~g} \mathrm{~L}^{-1},\left[\mathrm{Cu}^{2+}\right]=0.49 \mathrm{~g} \mathrm{~L}^{-1}$, and $\left[\mathrm{Ni}^{2+}\right]$ $=0.68 \mathrm{~g} \mathrm{~L}^{-1}$ to prepare the samples designated as ECOSA, ECUSA, and ENISA, respectively, and $\left[\mathrm{Co}^{2+}\right]=0.744 \mathrm{~g} \mathrm{~L}^{-1}$, $\left[\mathrm{Cu}^{2+}\right]=0.557 \mathrm{~g} \mathrm{~L}^{-1}$, and $\left[\mathrm{Ni}^{2+}\right]=0.748 \mathrm{~g} \mathrm{~L}^{-1}$ to prepare the samples designated as ECOZ, ECUZ, and ENIZ, respectively. The slurries of salt precursor and the matrix were maintained under stirring for $20 \mathrm{~h}$ at $40{ }^{\circ} \mathrm{C}$ at a $\mathrm{pH}$ value of $8-9$. After filtration and careful washing with distilled water, all the wet powders were dried at $100{ }^{\circ} \mathrm{C}$ for $2 \mathrm{~h}$ and eventually calcined at $550{ }^{\circ} \mathrm{C}$ for $4 \mathrm{~h}$.

The samples designated ICOSA, ICUSA, and INISA were prepared by impregnating the SA matrix at the imbibition point with aqueous concentrations of cobalt, copper, and nickel acetates, respectively $\left(\left[\mathrm{Co}^{2+}\right]=0.68 \mathrm{~g} \mathrm{~L}^{-1},\left[\mathrm{Cu}^{2+}\right]=0.49 \mathrm{~g}\right.$ $\mathrm{L}^{-1}$, and $\left.\left[\mathrm{Ni}^{2+}\right]=0.68 \mathrm{~g} \mathrm{~L}^{-1}\right)$. First, the SA matrix was outgassed and thermostated in an ice bath (ca. $2{ }^{\circ} \mathrm{C}$ ), then the solution containing the salt precursor was slowly added, maintaining the wet powder at about $7-8 \mathrm{kPa}$ and $2{ }^{\circ} \mathrm{C}$ during the imbibition step. The powder was dried by raising the temperature gently to $95^{\circ} \mathrm{C}$ under vacuum $(1 \mathrm{kPa})$ for $2 \mathrm{~h}$. The step of imbibition was repeated twice in order to introduce the whole amount of salt precursor in the matrix. The dried powder was calcined at $550{ }^{\circ} \mathrm{C}$ for $4 \mathrm{~h}$.

The samples designated MCOSA, MCUSA, and MNISA were prepared by mechanical mixing, usually called solid-state ion-exchange, of a dosed amount of SA (5 g) and cobalt, copper, and nickel acetylacetonate, $1.70,1.78$, and $1.69 \mathrm{~g}$, respectively (Strem $>98 \%$ purity). The solid mixture was homogenized in a ball mill for $2 \mathrm{~h}$, heated in argon atmosphere at $300{ }^{\circ} \mathrm{C}$ for 2 $\mathrm{h}$, and eventually calcined at $550{ }^{\circ} \mathrm{C}$ for $4 \mathrm{~h}$.

The metal ion content for all the samples is presented in Table 1.

Physicochemical Measurements. Chemical analysis for the determination of $\mathrm{Co}, \mathrm{Cu}$, and $\mathrm{Ni}$ amounts was performed by ICP (inductive coupled plasma, from Spectro) after dissolution of the sample in aqua regia and $\mathrm{HF}$, then a solution of $\mathrm{HCl}$ was made.

X-ray powder diffraction patterns (XRD) of the samples were collected on a computer-controlled Philips diffractometer equipped with a nickel-filtered $\mathrm{Cu} \mathrm{K} \alpha$ radiation $(\lambda=1.54178 \AA)$.

Surface areas were determined from conventional $\mathrm{N}_{2}$ adsorption isotherms using a 1900 Series Sorptomatic apparatus from Fisons Instruments. The samples $(0.1 \mathrm{~g})$ were heated at $350{ }^{\circ} \mathrm{C}$ overnight under vacuum (ca. $20 \mathrm{~h}, 10^{-1} \mathrm{~Pa}$ ) to remove moisture before the analysis.

Calorimetric and volumetric gas-solid titrations of the acid sites of the samples were performed by using $\mathrm{NH}_{3}$ (Air Liquide, purity $>99.9 \%$ ) as a probe. Before use, $\mathrm{NH}_{3}$ was first dried on sodium wires and then purified by successive freeze-thaw pumping cycles. The sample $(0.01 \mathrm{~g})$ was put in a quartz calorimetric cell and pretreated overnight (ca. $16 \mathrm{~h}$ ) at $350{ }^{\circ} \mathrm{C}$ under vacuum $\left(10^{-2} \mathrm{~Pa}\right)$.

Heats of adsorption were measured in a Setaram differential heat-flow microcalorimeter (Calvet C80) with an attached vacuum system for catalyst treatment and probe molecule dosing. A temperature of adsorption of $80{ }^{\circ} \mathrm{C}$ was chosen in order to limit physisorption. Small successive $\mathrm{NH}_{3}$ doses were sequentially adsorbed onto the samples to a final ammonia 
TABLE 1: Composition and Characteristics of the Samples

\begin{tabular}{|c|c|c|c|c|c|}
\hline \multirow[b]{2}{*}{$\begin{array}{l}\text { sample } \\
\text { code }\end{array}$} & \multicolumn{2}{|c|}{ loading } & \multirow{2}{*}{$\begin{array}{c}\text { surface } \\
\text { area } \\
\left(\mathrm{m}^{2} \mathrm{~g}^{-1}\right)\end{array}$} & \multicolumn{2}{|c|}{ porosity } \\
\hline & (wt \%) & $\left(\mathrm{mmol} \mathrm{g}^{-1}\right)$ & & $R_{\mathrm{p}, \mathrm{av}}(\AA)$ & $\begin{array}{c}V_{\mathrm{p}, \mathrm{Tot}} \\
\left(\mathrm{cm}^{3} \mathrm{~g}^{-1}\right)\end{array}$ \\
\hline ECOSA & 5.67 & 0.962 & 270 & 47.1 & 0.64 \\
\hline ECUSA & 8.02 & 1.262 & 285 & 43.7 & 0.62 \\
\hline ENISA & 6.52 & 1.111 & 357 & 33.0 & 0.59 \\
\hline ICOSA & 7.10 & 1.205 & 355 & 38.9 & 0.69 \\
\hline ICUSA & 5.88 & 0.925 & 318 & 40.7 & 0.65 \\
\hline INISA & 6.48 & 1.104 & 341 & 39.4 & 0.67 \\
\hline MCOSA & 5.64 & 0.957 & 252 & 48.7 & 0.61 \\
\hline MCUSA & 9.19 & 1.446 & 287 & 43.4 & 0.62 \\
\hline MNISA & 6.23 & 1.061 & 379 & 36.6 & 0.69 \\
\hline ECOZ & 5.16 & 0.876 & 290 & 20.2 & 0.32 \\
\hline ECUZ & 6.46 & 1.017 & 405 & 14.7 & 0.30 \\
\hline ENIZ & 5.84 & 0.995 & 413 & 16.6 & 0.37 \\
\hline $\mathrm{SA}^{a}$ & & & 365 & 43.1 & 0.79 \\
\hline $\mathrm{Z}^{b}$ & & & 555 & 12.0 & 0.30 \\
\hline
\end{tabular}

${ }^{a} \mathrm{SA}, \mathrm{Al}_{2} \mathrm{O}_{3}=13.50 \mathrm{wt} \% \cdot{ }^{b} \mathrm{Z}, \mathrm{Al}_{2} \mathrm{O}_{3}=2.90 \mathrm{wt} \% .{ }^{c}$ Determined by full BET equation.

pressure of about $133 \mathrm{~Pa}$ to titrate all the surface acid sites from highest to lowest strength. The equilibrium pressure relevant to each adsorbed amount was measured by means of a differential Barocel capacitance manometer. Furthermore, to calculate the irreversibly chemisorbed amount (Virr), the sample was pumped at the adsorption temperature $\left(80^{\circ} \mathrm{C}\right)$ at the end of the adsorption, and a second adsorption was then performed at the same temperature. Virr was determined from the difference between the first and second isotherms. The volumetric and calorimetric data were stored and analyzed by microcomputer processing.

XPS analyses were carried out with a SSI model M-probe spectrometer using focused (diameter of the irradiated area: 600 $\mu \mathrm{m})$ monochromatic $\mathrm{Al} \mathrm{K} \alpha$ radiation $(10 \mathrm{kV}, 12 \mathrm{~mA})$. The residual pressure inside the analysis chamber was about $5 \times$ $10^{-8} \mathrm{~Pa}$. The sample charging effects were minimized with a low-energy flood gun $(5 \mathrm{eV})$. The spectra were recorded in the constant pass energy mode ( $150 \mathrm{eV}$ for the quantitative analyses, $50 \mathrm{eV}$ for the high-resolution analyses).

The XPS peaks were decomposed into subcomponents using a Gaussian (80\%)-Lorentzian (20\%) curve fitting program with a nonlinear background. ${ }^{71}$ The quantitative analyses were performed with the sensitivity factors given by Scofield ${ }^{72}$ from the intensities of $\mathrm{M} 2 \mathrm{p}^{3 / 2}(\mathrm{M}=\mathrm{Co}, \mathrm{Cu}, \mathrm{Ni}), \mathrm{Si} 2 \mathrm{~s}$, and $\mathrm{Al} 2 \mathrm{~s}$ (the $\mathrm{Cu} 3 \mathrm{p}$ and $\mathrm{Ni} 3 \mathrm{p}$ peaks partly overlap the $\mathrm{Al} 2 \mathrm{p}$ peak and it is the same for Co $3 p$ and $\mathrm{Si} 2 \mathrm{p}$ ). The transmission, $T$, of the spectrometer and the electron mean free path, $\lambda$, were given by the following relation: $\lambda T=E_{\mathrm{k}}{ }^{0.7}$, where $E_{\mathrm{k}}$ is the kinetic energy of the photoelectrons. The calibration of the spectra was performed with the Si 2p line from the silica-alumina (103.2 $\mathrm{eV})$ and ZSM-5 support (103.3 eV). These references, in agreement with the literature data, were verified in the pure supports and were consistent with the $\mathrm{C} 1 \mathrm{~s}$ peak of adventitious carbon at a binding energy (BE) of $284.8 \mathrm{eV}$. With these references, the other $\mathrm{BE}$ are measured for silica-alumina at $154.2 \pm 0.1$ (Si 2s), $75.0 \pm 0.1(\mathrm{Al} 2 \mathrm{p})$, and $119.6 \pm 0.1 \mathrm{eV}$ (Al 2s) and for zeolite at 154.2 \pm 0.1 (Si 2s), $74.7 \pm 0.1$ (Al $2 \mathrm{p}$ ), and $119.2 \pm 0.1 \mathrm{eV}(\mathrm{Al} 2 \mathrm{~s})$. Full width at half-maximum (fwhm) of Si $2 \mathrm{p}$ and $\mathrm{Al} 2 \mathrm{p}$ peaks are about 2 and $2.2 \mathrm{eV}$, respectively.

After $\mathrm{NH}_{3}$ exposure, all the samples were taken off from the calorimetric cell and investigated by XPS spectroscopy. As zeolites present often a surface composition different from that of the bulk (dealumination, migration of cations, etc.), the XPS spectra of the zeolite samples were collected on ground samples for a better comparison between XPS and calorimetric data. Previous studies showed that the surface composition determined by XPS was much closer to that of the bulk when using ground samples. ${ }^{30}$

The N 1s bands were decomposed into two components (vide infra) with fwhm between 2.0 and $2.3 \mathrm{eV}$ depending on the samples.

\section{Results and Discussion}

Characteristics of Samples. Various series of samples were prepared with a loading amount of about $1 \mathrm{mmol} / \mathrm{g}$ of $\mathrm{Co}, \mathrm{Cu}$, and $\mathrm{Ni}$ cations (from acetate salts) on amorphous silica-alumina and crystalline ZSM-5 matrixes by three different methods of preparation (Table 1). Conventional ion exchange (E), impregnation at imbibition point (I), and solid-state ion-exchange (M) procedures were used. ${ }^{60,73}$ All the catalysts prepared were tested in the $\mathrm{NO}$ decomposition to $\mathrm{N}_{2}$ and $\mathrm{O}_{2}$, and the results have been presented elsewhere. ${ }^{66}$ Moreover, the catalysts containing $\mathrm{Cu}$, were thoroughly studied by $\mathrm{NO}$ adsorption in order to determine the copper site energy distribution as a function of the support matrix and of the preparation procedure. ${ }^{74}$

X-ray patterns of the three metal-loaded zeolites (ECOZ, ECUZ, and ENIZ) were typical of crystalline ZSM-5 and did not reveal any XRD lines related to oxide phases or to metal oxide clusters. This did not exclude the presence of small oxide clusters of severals nanometers in size that do not show X-ray diffraction. The metal-loaded silica-alumina samples presented XRD patterns typical of amorphous solids. However, XRD of the samples prepared by solid-state ion exchange and impregnation procedures (MCOSA, MCUSA, and MNISA and ICOSA, ICUSA, and INISA) presented some weak but distinct lines attributable to separate oxide phases $\mathrm{CoO}, \mathrm{CuO}$, and $\mathrm{NiO}$. The XRD of the samples prepared by ion exchange (ECOSA, ECUSA, and ENISA) did not reveal any lines due to segregated oxide cluster, indicating a good dispersion of the metalcontaining phase on the amorphous oxide matrix. Figure 1 depicts the XRD patterns of the Ni-based samples, chosen as examples.

In Table 1, the list of catalysts and relevant matrixes studied with their principal characteristics is presented. For the series of zeolite catalysts prepared by ion-exchange (ECOZ, ECUZ, and ENIZ), the metal loading was much greater than the exchange capacity of the parent ZSM-5. ${ }^{75}$ The ratio between the total charges introduced, calculated from the amounts of loaded metal ion, and the Al moles of the zeolite structure (2 $\mathrm{M}^{2+} / \mathrm{Al}$ ) indicates an excess of charge. The two $\mathrm{M}^{2+} / \mathrm{Al}$ ratios exceed 1 for all the three zeolite catalysts $(3.24,3.82$, and 3.72 for ECOZ, ECUZ, and ENIZ, respectively).

The zeolite catalysts maintained microporous properties, in particular ECUZ, as revealed by the high value of pore volume and the low value of average pore radius, calculated by the classical Gurvitsh rule (Table 1). The textural properties of the three zeolite catalysts in comparison with the properties of the ZSM-5 matrix have been recently presented in the literature. ${ }^{75}$ Concerning the amorphous catalysts, they displayed all mesoporous character and the average pore radius was in all cases about $42 \AA$. The textural properties of the silica-alumina were not remarkably affected by the deposition of the metal ions, whatever the method of deposition. The samples containing $\mathrm{Ni}$ (ENISA, INISA, and MNISA) presented in any case high values of surface area that were close to that of the respective parent matrix. The samples containing $\mathrm{Co}$ and $\mathrm{Cu}$ had lower surfaces when prepared by ion exchange and solid-state ion exchange (ECOSA and ECUSA and MCOSA and MCUSA), whereas 


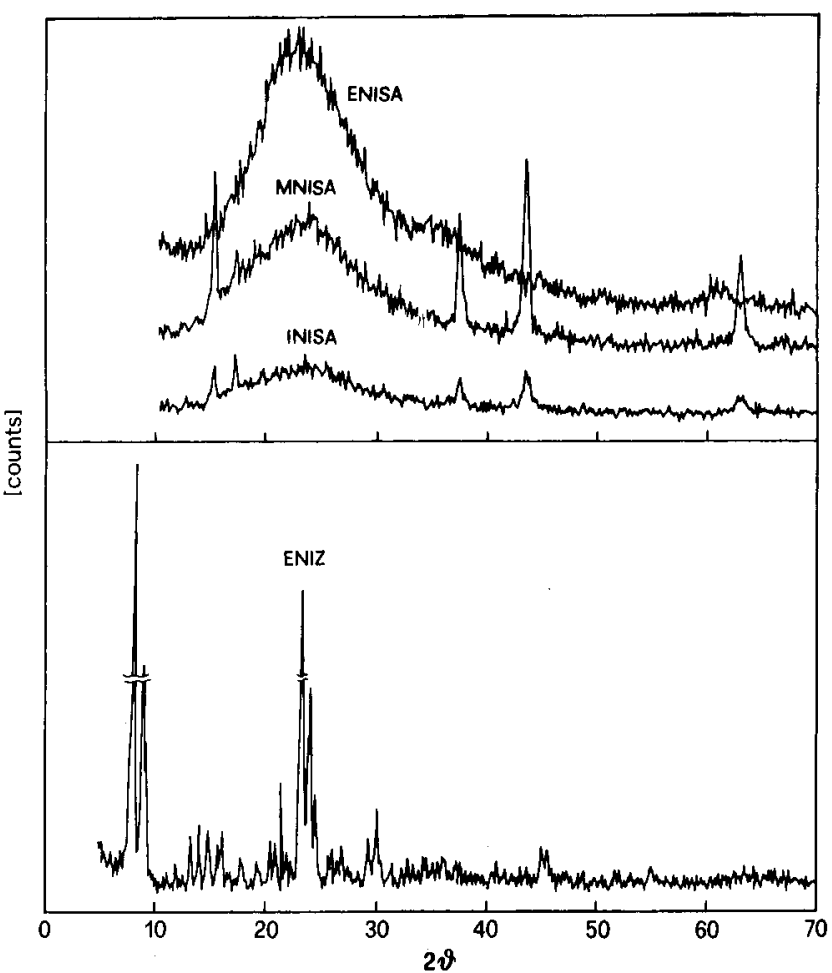

Figure 1. XRD patterns of the samples containing Ni differently prepared: by ion-exchange, ENISA, by impregnation, INISA, and by mixing (solid-state ion exchange), MNISA on silica-alumina and by ion-exchange, ENIZ, on ZSM.5.

higher values were found in the case of the catalysts prepared by impregnation (ICOSA and ICUSA).

The chemical state of the metal ions deposited on the amorphous and crystalline matrixes by the three preparation methods (E, I, and $\mathrm{M}$ ) was determined by measuring the $\mathrm{BE}$ of Co $2 \mathrm{p}^{3 / 2}, \mathrm{Cu} 2 \mathrm{p}^{3 / 2}$, and $\mathrm{Ni} 2 \mathrm{p}^{3 / 2}$ associated with the electron ejection from the $2 \mathrm{p}^{3 / 2}$ atomic orbital of the metal ions (Figures 2-4). The XP spectra of the studied samples have been compared with the spectra of $\mathrm{CoO}, \mathrm{Cu}_{2} \mathrm{O}, \mathrm{CuO}$, and $\mathrm{NiO}$ oxides. In contrast to $\mathrm{Co}$ and $\mathrm{Ni}$ samples, the $\mathrm{Cu}$ samples underwent photoreduction during data collection by the X-ray flux, causing the intensity of the peaks due to $\mathrm{Cu} 2 \mathrm{p}^{3 / 2}$ of $\mathrm{Cu}$ (II) to decrease and that of $\mathrm{Cu}(\mathrm{I})$ to increase with the time of exposure to X-rays. This phenomenon was minimized and could be considered as negligible in our case where the recording time for this peak was always very short (less than $4 \mathrm{~min}$ ). The bands corresponding to the bivalent oxidation state, $\mathrm{M}(\mathrm{II})$, are rather complex because they present several satellites (shake-up due to electrontransfer ligand-metal and multiplet splitting). The main peaks of $\mathrm{CoO}, \mathrm{CuO}$, and $\mathrm{NiO}$ oxides were found at 779.5, 934, and $853.2 \mathrm{eV}$, respectively; these values are very close to those in the literature. ${ }^{76}$ The spectra of $\mathrm{Cu}(\mathrm{I})$ and $\mathrm{Cu}_{2} \mathrm{O}$, like that of $\mathrm{Cu}-$ (0), do not show any satellites $\left(\mathrm{Cu} 2 \mathrm{p}^{3 / 2}, \mathrm{BE}=932.2 \mathrm{eV}\right)$. In Figures $2-4$, the theoretical components associated with $\mathrm{CoO}$, $\mathrm{Cu}_{2} \mathrm{O}$, and $\mathrm{NiO}$ have been colored in gray in order to distinguish them from the components associated with other metal species present in the studied samples.

The XP spectra of the $\mathrm{Co}, \mathrm{Cu}$, and $\mathrm{Ni}$ samples prepared by ion exchange $(\mathrm{E})$ on the amorphous as well as on the crystalline support showed an unique oxidation state of the metal ions, $\mathrm{M}(\mathrm{II})$. The $2 \mathrm{p}^{3 / 2}$ bands of the metal ions are shifted toward high binding energies with respect to the values typical of the relevant bulk oxides (Table 2). The shift is indicative of a charge transfer from the metal ions toward the support matrix, that is, a strong interaction between the metal ions and the matrix. The metal

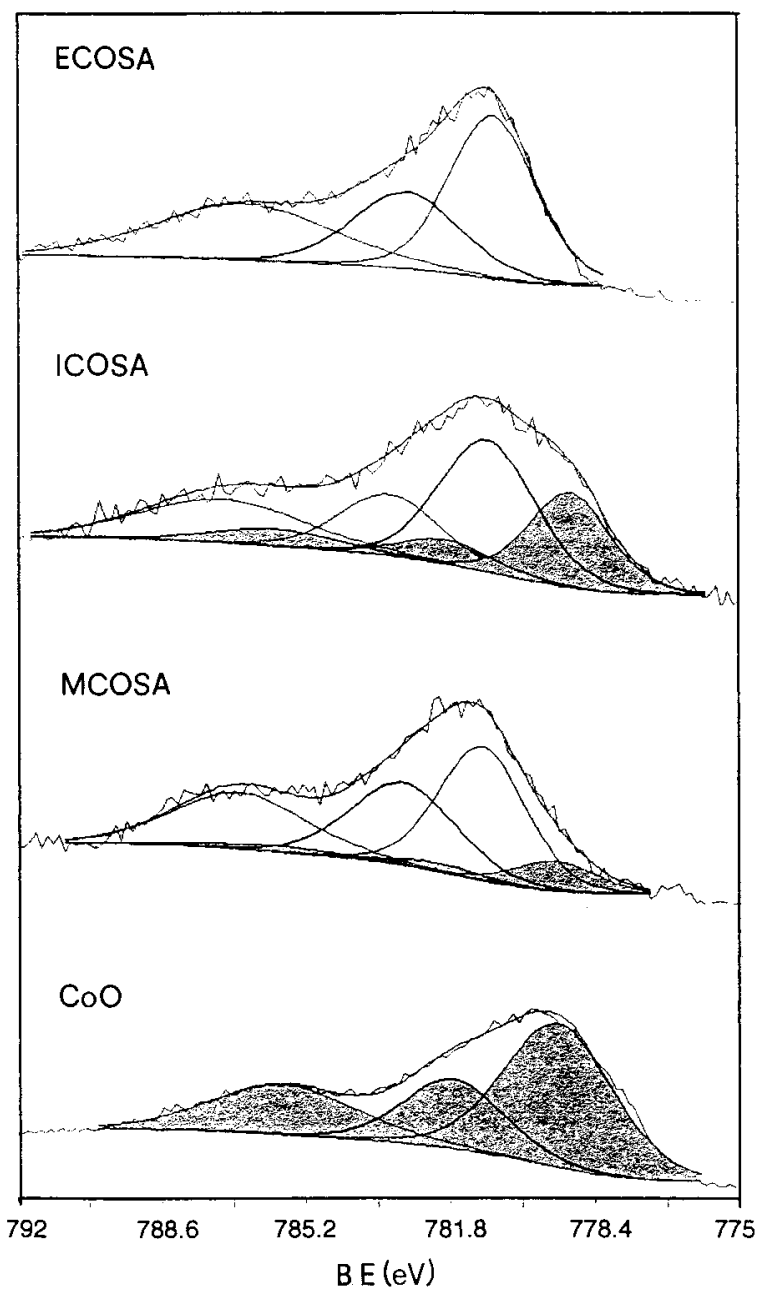

Figure 2. Experimental and decomposed Co $2 \mathrm{p}^{3 / 2} \mathrm{XP}$ spectra on the samples prepared by ion-exchange procedure (ECOSA), wetness impregnation (ICOSA), and mechanical mixing (solid-state ion exchange) (MCOSA), compared with that of $\mathrm{CoO}$ oxide.

ion-matrix interaction reflects a good surface concentration of the metal phases, stabilized as isolated ions rather than as oxide clusters.

The samples prepared by impregnation (I) and solid-state ionexchange $(\mathrm{M})$ presented a pronounced heterogeneous character due to the presence of the metal phase in different oxidation states (in the case of $\mathrm{Cu}$-based samples) and in different environmental situations (in the case of $\mathrm{Co}$ and $\mathrm{Ni}$ samples). XP spectra of ICUSA and MCUSA displayed large bands at low BE (930-935 eV), which could be decomposed into two components, one corresponding to $\mathrm{Cu}$ (II) ions in interaction with the oxide matrix and the other to $\mathrm{Cu}(\mathrm{I})$ ions. The concentration of the reduced $\mathrm{Cu}$ ions, which are known to be stable in an air atmosphere, was estimated to be not higher than $20-30 \%$. Coand Ni-based samples presented complex XP spectra, indicating the presence of both isolated metal ions (higher BE) and separate oxides (lower BE). In the case of Ni-based samples, about $40 \%$ of $\mathrm{Ni}$ ions were present as separate oxide.

The dispersion of the metal ions M(II) can be correlated with the ratio $(\alpha)$ of the surface concentrations evaluated by XPS, $\alpha$ $=\mathrm{M}(\mathrm{II}) /(\mathrm{Al}+\mathrm{Si})$. Table 2 lists the experimental values of $\alpha$, compared with the ratios calculated from the catalyst composition as determined by chemical analysis. These latter are in any case lower than the $\alpha$ values, as most of the ions are present on the surface. 


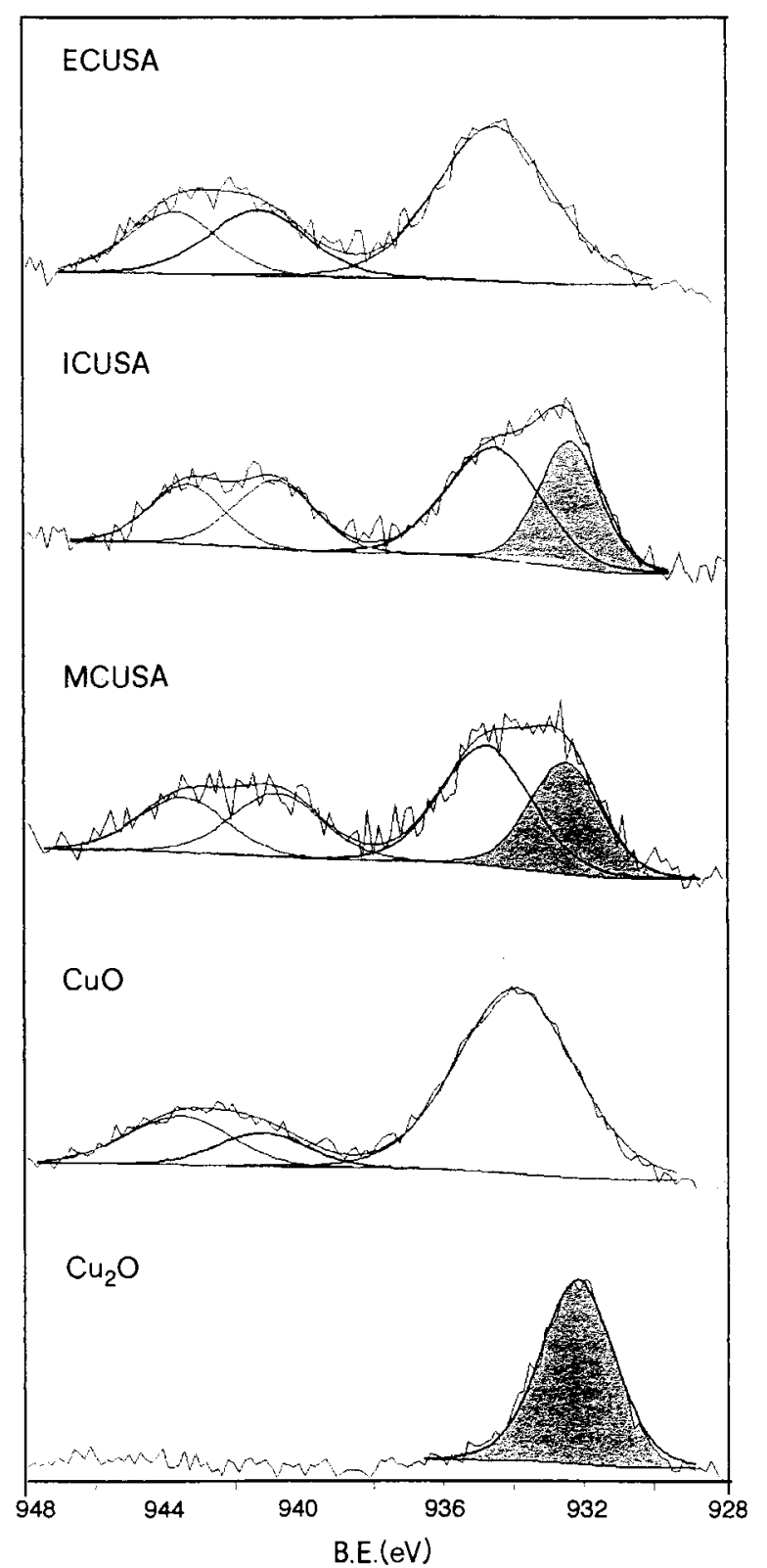

Figure 3. Experimental and decomposed $\mathrm{Cu} 2 \mathrm{p}^{3 / 2} \mathrm{XP}$ spectra on the samples prepared by ion-exchange procedure (ECUSA), wetness impregnation (ICUSA), and mechanical mixing (solid-state ion exchange) (MCUSA), compared with that of $\mathrm{CuO}$ and $\mathrm{Cu}_{2} \mathrm{O}$ oxides.

The catalysts prepared by ion exchange (E) on an amorphous as well as on a crystalline matrix had high surface concentrations of the metal ions, with $\alpha$ values ranging in the $0.16-0.18$ interval for the $\mathrm{Cu}$-containing samples, $0.23-0.27$ for $\mathrm{Co}$ samples, and $0.27-0.40$ for Ni samples. Taking into account the exponential decay law of the XPS signal as well as the mean free path of the photoelectrons in oxide materials ${ }^{77}$ (from 1.4 to $2 \mathrm{~nm}$ as a function of the kinetic energy), the experimental values of $\alpha$ corresponded approximately to a monolayer deposition of the metal phase. The values of the metal ion concentration for the samples with a zeolite matrix could be underestimated as the ions are also present in the channels and pores of ZSM-5 where they could be hardly detected by the spectroscopic analysis.

Very low values of $\alpha$ were found for the samples prepared by impregnation (I) and solid-state ion exchange (M). The presence of metal oxide aggregates on the surface could be invoked in this case. Moreover, the feature of the $2 \mathrm{p}^{3 / 2} \mathrm{XP}$ bands

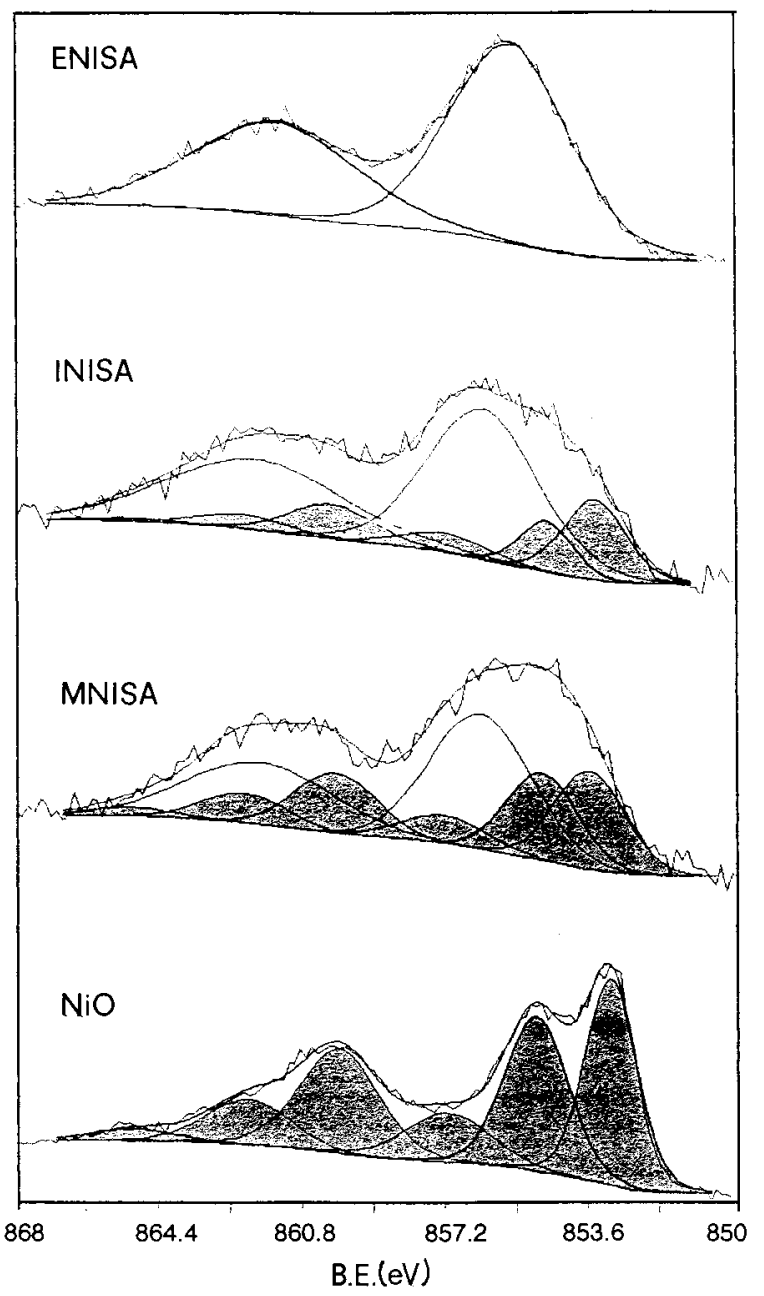

Figure 4. Experimental and decomposed $\mathrm{Ni} 2 \mathrm{p}^{3 / 2} \mathrm{XP}$ spectra on the samples prepared by ion-exchange procedure (ENISA), wetness impregnation (INISA), and mechanical mixing (solid-state ion-exchange) (MNISA), compared with that of $\mathrm{NiO}$ oxide.

was consistent with a poor surface concentration of the metal phase and with a poor intimate contact between the metal ions and the matrix. In fact, peaks similar to bulk $\mathrm{CoO}, \mathrm{NiO}$, and $\mathrm{Cu}_{2} \mathrm{O}$ appeared, as described above.

Adsorption Calorimetry. Ammonia, as a basic probe to titrate the surface sites of acid catalysts, has been widely used. ${ }^{8,9,78}$ The molecular structures of $\mathrm{NH}_{3}$ adsorbed on surface acid sites are well-known: ${ }^{44,79,80} \mathrm{H}$-bonding to a surface oxygen atom, proton transfer from a surface hydroxyl to the $\mathrm{NH}_{3}$ adsorbate, coordination to an electron-deficient metal atom. Therefore, $\mathrm{NH}_{3}$ proved to be a reliable probe when both Brönsted and Lewis acid sites were investigated.

The differential heats of $\mathrm{NH}_{3}$ adsorption as a function of coverage on ZSM-5 and SA surfaces are shown in Figure 5. The heats of adsorption of $\mathrm{NH}_{3}$ on the ZSM-5 lay considerably above those of the silica-alumina, both in the initial region of coverage and up to adsorption values near reversible adsorption $\left(\mathrm{NH}_{3}\right.$ physisorption), indicating a superior acid character of ZSM-5 with respect to $\mathrm{SiO}_{2}-\mathrm{Al}_{2} \mathrm{O}_{3}$. This result was expected on the basis of the knowledge of the literature on the subject. ${ }^{55}$

For ZSM-5, there was an indication for some strong sites evidenced by initially high differential heats, above $150 \mathrm{~kJ} / \mathrm{mol}$, which could be associated with nonframework aluminum species. Then, upon increasing $\mathrm{NH}_{3}$ coverage, ZSM-5 showed Brönsted acid sites of varying strength as shown by the continuous decrease of the differential heat curve. The dif- 
TABLE 2: Binding Energies (BE) (in $\mathrm{eV}$ ) of $\mathrm{Co} 2 \mathrm{p}^{3 / 2}, \mathrm{Cu} 2 \mathrm{p}^{3 / 2}$, and $\mathrm{Ni} 2 \mathrm{p}^{3 / 2}$ on the Studied Samples

\begin{tabular}{llllr}
\hline \multirow{2}{*}{ metal species } & \multicolumn{3}{c}{ preparation } \\
\cline { 2 - 5 } & \multicolumn{1}{c}{$\mathrm{E}(\mathrm{M}) \mathrm{Z}$} & $\mathrm{E}(\mathrm{M}) \mathrm{SA}$ & $\mathrm{I}(\mathrm{M}) \mathrm{SA}$ & \\
$\mathrm{Co}(\mathrm{II})$ & $781.1(100 \%)^{a}$ & $781.0(100 \%)^{a}$ & $781.3(70 \%)^{a}$ & $781.4(85 \%)^{a}$ \\
$\mathrm{CoO}$ & & & $779.4(30 \%)^{a}$ & $779.6(15 \%)^{a}$ \\
$\alpha=\mathrm{Co} /(\mathrm{Si}+\mathrm{Al})^{b}$ & $0.23(0.06)^{c}$ & $0.27(0.06)^{c}$ & $0.09(0.08)^{c}$ & $0.06(0.06)^{c}$ \\
$\mathrm{Cu}(\mathrm{II})$ & $934.6(100 \%)^{a}$ & $935.2(100 \%)^{a}$ & $934.9(80 \%)^{a}$ & $935.1(70 \%)^{a}$ \\
$\mathrm{Cu}(\mathrm{I})$ & & & $932.8(20 \%)^{a}$ & $932.8(30 \%)^{a}$ \\
$\alpha=\mathrm{Cu} /(\mathrm{Si}+\mathrm{Al})^{b}$ & $0.18(0.07)^{c}$ & $0.16(0.08)^{c}$ & $0.06(0.06)^{c}$ & $0.05(0.06)^{c}$ \\
$\mathrm{Ni}(\mathrm{II})$ & $855.9(100 \%)^{a}$ & $856.0(100 \%)^{a}$ & $856.4(60 \%)^{a}$ & $856.7(55 \%)^{a}$ \\
$\mathrm{NiO}$ & & & $853.6(40 \%)^{a}$ & $853.9(45 \%)^{a}$ \\
$\alpha=\mathrm{Ni} /(\mathrm{Si}+\mathrm{Al})^{b}$ & $0.40(0.06)^{c}$ & $0.27(0.07)^{c}$ & $0.07(0.07)^{c}$ & $0.04(0.07)^{c}$
\end{tabular}

${ }^{a}$ Percent of relative amount of the metal species evaluated by XPS. ${ }^{b}$ Surface concentration of the metal species evaluated by XPS. ${ }^{c}$ Concentration of the metal species calculated from chemical analysis.

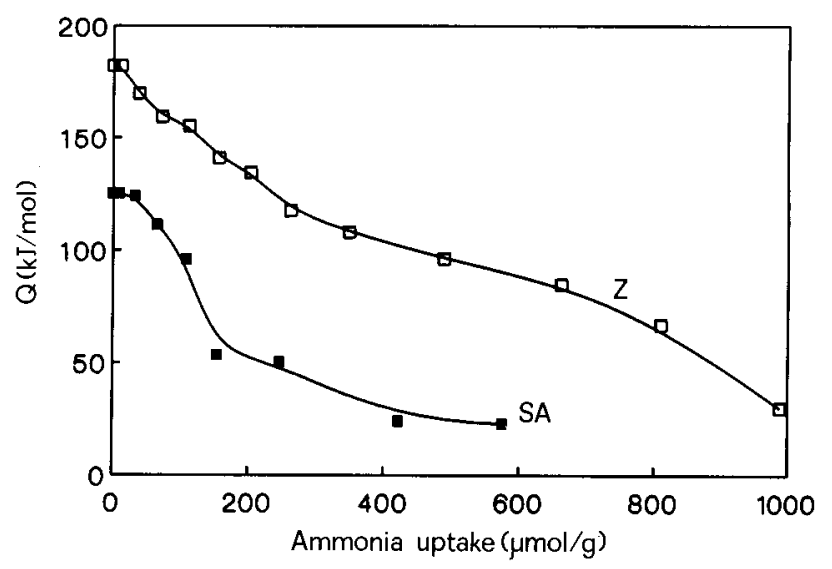

Figure 5. Differential heat of adsorption of $\mathrm{NH}_{3}$ over silica-alumina, SA, and ZSM-5, Z, supports.

ferential heat curve as a function of $\mathrm{NH}_{3}$ coverage for SA showed a small plateau around $125 \mathrm{~kJ} / \mathrm{mol}$ followed by a drastic decrease to heats around $50 \mathrm{~kJ} / \mathrm{mol}$. The total number of sites was larger for ZSM-5 compared to SA, as expected from the peculiar structure of the zeolite which possesses much internal acidity.

Figure 6 shows the site strength distribution obtained from the differential heat curve of adsorption as a function of $\mathrm{NH}_{3}$ coverage for the various metal ion-loaded samples in comparison with the relevant support (SA or Z), grouped by the preparation methods. The number of acid sites (nondissociative chemisorption of $\mathrm{NH}_{3}$ with 1:1 stoichiometry was assumed) of given enthalpy $\left(Q, \mathrm{~kJ} / \mathrm{mol}_{\mathrm{NH}_{3}}\right)$, that is acid strength, is presented within four intervals: $Q>150 ; 150>Q>125 ; 125>Q>100$; $100>Q>50$.

Most of the sites of the SA matrix had acid strengths in the range $50-125 \mathrm{~kJ} / \mathrm{mol}_{\mathrm{NH}_{3}}\left(153\right.$ and $85 \mu \mathrm{mol}_{\mathrm{NH}_{3}} / \mathrm{g}$ for the enthalpy interval 50-100 and $100-125 \mathrm{~kJ} / \mathrm{mol}_{\mathrm{NH}_{3}}$, respectively). Several acid sites with high enthalpy $\left(Q>125 \mathrm{~kJ} / \mathrm{mol}_{\mathrm{NH}_{3}}\right)$ were also present $\left(96 \mu \mathrm{mol}_{\mathrm{NH}_{3}} / \mathrm{g}\right)$.

As can be seen from Figure 6, the deposition of metal ions on SA by the ion exchange procedure (E) deeply modified the acidity feature of the matrix in terms of number and strength of acid sites. The sample with nickel ions showed the highest number of strong sites with adsorption enthalpy between 125 and $150 \mathrm{~kJ} / \mathrm{mol}_{\mathrm{NH}_{3}}\left(123 \mu \mathrm{mol}_{\mathrm{NH}_{3}} / \mathrm{g}\right)$. The sample with cobalt ions presented a few strong sites above $150 \mathrm{~kJ} / \mathrm{mol}\left(26 \mu \mathrm{mol}_{\mathrm{NH}_{3}} /\right.$ g). The sample with $\mathrm{Cu}$ ions had the most homogeneous character with respect to its acid sites, only sites with enthalpies in the range 50-125 were evidenced (247 and $130 \mu \mathrm{mol}_{\mathrm{NH}_{3}} / \mathrm{g}$ for the interval $50-100$ and $100-125 \mathrm{~kJ} / \mathrm{mol}_{\mathrm{NH}_{3}}$, respectively). As for the amount of acid sites with adsorption enthalpy between 100 and $125 \mathrm{~kJ} / \mathrm{mol}_{\mathrm{NH}_{3}}$, the obtained trend was in the order SA
$<$ ENISA $\leq$ ECOSA $<$ ECUSA, and the amounts of weak acid sites, between 50 and $100 \mathrm{~kJ} / \mathrm{mol}_{\mathrm{NH}_{3}}$, followed the same sequence.

The samples prepared by the wetness impregnation method (I) showed a completely different feature, as can be seen in Figure 6. In this case, strong acid sites (above $125 \mathrm{~kJ} / \mathrm{mol}_{\mathrm{NH}_{3}}$ ) were created by the addition of the metal ions. The sample with $\mathrm{Ni}$ ions showed the highest increase of the number of acid sites with enthalpy between 125 and $150 \mathrm{~kJ} / \mathrm{mol}_{\mathrm{NH}_{3}}\left(49 \mu \mathrm{mol}_{\mathrm{NH}_{3}} / \mathrm{g}\right)$. Significant strong sites $\left(Q>150 \mathrm{~kJ} / \mathrm{mol}_{\mathrm{NH}_{3}}\right)$ were created on the ICUSA sample $\left(50 \mu \mathrm{mol}_{\mathrm{NH}_{3}} / \mathrm{g}\right)$ compared to those generated by the deposition of Co and Ni ions (ICOSA and INISA samples with 22 and $24 \mu \mathrm{mol}_{\mathrm{NH}_{3}} / \mathrm{g}$, respectively).

Concerning the samples prepared by solid-state ion exchange (M), the results of microcalorimetric measurements of the differential heat of $\mathrm{NH}_{3}$ showed that the acid features of the metal ion containing samples were not remarkably different from those of the SA support. MCUSA and MCOSA samples contained about 132 and $143 \mu \mathrm{mol}_{\mathrm{NH}_{3}} / \mathrm{g}$ of acid sites, respectively, of acid strength greater than $100 \mathrm{~kJ} / \mathrm{mol}_{\mathrm{NH}_{3}}$, while the amount of such sites for the MNISA remained close to that of SA matrix (85 and $95 \mu \mathrm{mol}_{\mathrm{NH}_{3}} / \mathrm{g}$, respectively).

For the zeolitic samples prepared by ion-exchange (ECOZ, ECUZ, and ENIZ), the most significant difference compared with the acidity of the ZSM-5 matrix was the remarkable increase of the amount of acid sites which adsorbed $\mathrm{NH}_{3}$ with enthalpies between 125 and $150 \mathrm{~kJ} / \mathrm{mol}_{\mathrm{NH}_{3}}$ observed for the samples containing $\mathrm{Cu}$ and $\mathrm{Ni}$ ions (306 and $255 \mu \mathrm{mol}_{\mathrm{NH}_{3}} / \mathrm{g}$, respectively, compared to $108 \mu \mathrm{mol}_{\mathrm{NH}_{3}} / \mathrm{g}$ of ZSM-5) (Figure $6)$. The total number of acid sites with enthalpies lower than $125 \mathrm{~kJ} / \mathrm{mol}_{\mathrm{NH}_{3}}$ remained close to that of the ZSM-5 matrix for all of the metal ion samples.

Figure 7 is aimed at showing the influence of the preparation method on the formation of acidity, by comparing the curves of differential heat of $\mathrm{NH}_{3}$ adsorption versus coverage for a given metal ion. It can be seen that, in any case, the samples based on ZSM-5 are always much more acidic than those based on silica-alumina. Therefore, the comparison among different preparation methods is valuable only for the SA samples.

For the differently prepared samples containing Co (ECOSA, ICOSA, and MCOSA), it can be seen (Figure 7) that the ion exchange method (ECOSA) led to a significant increase of the number and strength of the acid sites, despite that the amount of Co ions introduced is not the highest in this sample compared with the other samples containing Co. The acidities of ICOSA and MCOSA were very similar both in terms of number and strength of acid sites. The two curves of differential heat of $\mathrm{NH}_{3}$ adsorption were impossible to distinguish starting from $100 \mathrm{~kJ} / \mathrm{mol}_{\mathrm{NH}_{3}}$; for higher values of enthalpy changes, ICOSA presented some sites with very high acid strength. 

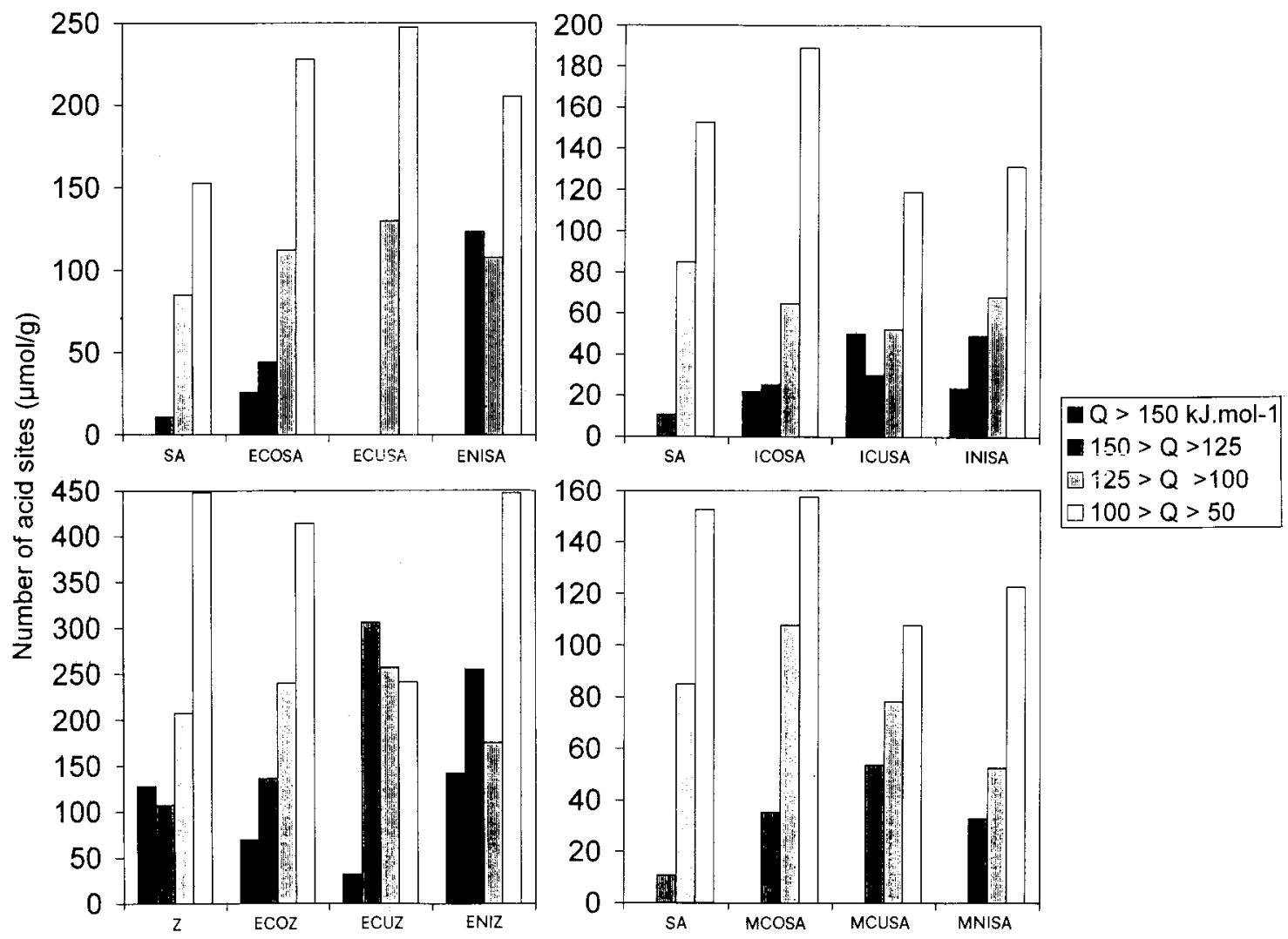

Figure 6. Distribution of acid sites derived from different differential heats of $\mathrm{NH}_{3}$ adsorption over samples prepared by ion-exchange on silicaalumina, E(M)SA, and on zeolite, E(M)Z, wetness impregnation, I(M)SA, and mechanical mixing (solid-state ion-exchange) M(M)SA.

Concerning the three SA-based samples containing $\mathrm{Cu}$ (ECUSA, ICUSA, MCUSA), the differential heat curves of $\mathrm{NH}_{3}$ adsorption (Figure 7) presented about the same number of acid sites which adsorbed $\mathrm{NH}_{3}$ with heats higher than $100 \mathrm{~kJ} / \mathrm{mol}$, but the strength of the acid sites was significantly different between the three samples. The initial heats of $\mathrm{NH}_{3}$ adsorption were in the order 160,140 , and $120 \mathrm{~kJ} / \mathrm{mol}$ for ICUSA, MCUSA, and ECUSA, respectively. In the domain of weak sites, the plots of differential heat curves for ICUSA and MCUSA were similar but ECUSA showed a larger amount of sites in the $50-80 \mathrm{~kJ} / \mathrm{mol}_{\mathrm{NH}_{3}}$ interval than the two other samples. The total number of acid sites of the three $\mathrm{Cu}$ samples was very close, but the acid strength distribution was significantly different. Figure 8 shows a better visualization of the acid site energy distribution of the $\mathrm{Cu}$-containing samples prepared on SA compared with the support matrix. The acidity spectra $(\mathrm{d} n /$ $\mathrm{d} Q$ vs $Q$ ) were obtained by computing the derivative of the previous curves of differential heats of $\mathrm{NH}_{3}$ adsorption. ECUSA had an acidity feature very close to that of SA, while the two samples prepared by impregnation and solid-state ion-exchange (ICUSA and MCUSA, respectively) presented some sites with higher acid strength than SA. These sites are probably associated with isolated $\mathrm{Cu}$ ions in coordinatively unsaturated positions (cus cations).

The differential heats of $\mathrm{NH}_{3}$ adsorption versus coverage on the Ni-loaded samples, depicted in Figure 7, showed a strengthening of the acid character of the three samples compared with the SA support (Figure 5). The number of strong sites with adsorption enthalpy above $100 \mathrm{~kJ} / \mathrm{mol}_{\mathrm{NH}_{3}}$ was found in the order: MNISA $\left(85 \mu \mathrm{mol}_{\mathrm{NH}_{3}} / \mathrm{g}\right)<$ INISA $\left(117 \mu \mathrm{mol}_{\mathrm{NH}_{3}} / \mathrm{g}\right)<$ ENISA $\left(231 \mu \mathrm{mol}_{\mathrm{NH}_{3}} / \mathrm{g}\right)$.

A means for deciding the extent of chemisorption within a global adsorption is to measure the part referred to physical adsorption by a dual adsorption method. After a first adsorption, a second one is repeated after evacuating between the two adsorptions. The amount of adsorbate "irreversibly" adsorbed (Virr), that is, chemisorbed, can then be obtained (Table 4). Virr is closely related with the acid sites having sufficient strength to play a decisive role in most catalytic processes. As a general trend, the samples prepared by ion exchange displayed the highest number of Virr, in accordance with the highest surface concentration of metal ions. When comparing the values of Virr of the $\mathrm{Cu}$ samples at a given equilibrium pressure (27 $\mathrm{Pa})$, the following order was found: ICUSA $\left(184 \mu \mathrm{mol}_{\mathrm{NH}_{3}} / \mathrm{g}\right)$ $<$ MCUSA $\left(222 \mu \mathrm{mol}_{\mathrm{NH}_{3}} / \mathrm{g}\right)<$ ECUSA $\left(275 \mu \mathrm{mol}_{\mathrm{NH}_{3}} / \mathrm{g}\right)$. For the Ni samples, the order became MNISA $\left(130 \mu \mathrm{mol}_{\mathrm{NH}_{3}} / \mathrm{g}\right)<$ INISA $\left(188 \mu \mathrm{mol}_{\mathrm{NH}_{3}} / \mathrm{g}\right)<$ ENISA $\left(288 \mu \mathrm{mol}_{\mathrm{NH}_{3}} / \mathrm{g}\right)$. The three Co samples had about the same value of Virr (203, 205, and $208 \mu \mathrm{mol}_{\mathrm{NH}_{3}} / \mathrm{g}$ for ICOSA, ECOSA, and MCOSA, respectively). For the ZSM-5-based catalysts, ECUZ and ENIZ showed similar total numbers of acid sites (956 and $994 \mu \mathrm{mol}_{\mathrm{NH}_{3}} / \mathrm{g}$, respectively) but the number of sites able to chemisorb $\mathrm{NH}_{3}$ (Virr) was more important for ECUZ (691 $\left.\mu \mathrm{mol}_{\mathrm{NH}_{3}} / \mathrm{g}\right)$ than for ENIZ (587 $\mu \mathrm{mol}_{\mathrm{NH}_{3}} / \mathrm{g}$ ).

XPS of $\mathbf{N H}_{3}$-Saturated Samples. The N 1s XP spectra of chemisorbed $\mathrm{NH}_{3}$ on the SA and ZSM-5 matrixes and on the samples loaded with $\mathrm{Co}, \mathrm{Cu}$, and $\mathrm{Ni}$ metal ions made it possible to distinguish Brönsted and Lewis acid sites and to evaluate their concentrations. This has been already proved with pyridine $^{30,39,56,81,82}$ as well as with ammonia ${ }^{30,83}$ adsorption. As the binding energy of any atom is influenced by its close environment, when $\mathrm{NH}_{3}$ is adsorbed on a Brönsted acid site, the nitrogen atom exhibits reduced electron density and it becomes surrounded by four hydrogen atoms $\left(\mathrm{NH}_{4}^{+}\right)$. A different behavior occurs when $\mathrm{NH}_{3}$ is adsorbed on a Lewis acid site; the nitrogen atom becomes now surrounded by three hydrogen atoms plus a metal ion (in the present case, $\mathrm{Al}, \mathrm{Co}, \mathrm{Cu}$, or $\mathrm{Ni}$ ). The chemical shift associated with the $\mathrm{N}$ 1s orbital would not be the same in 

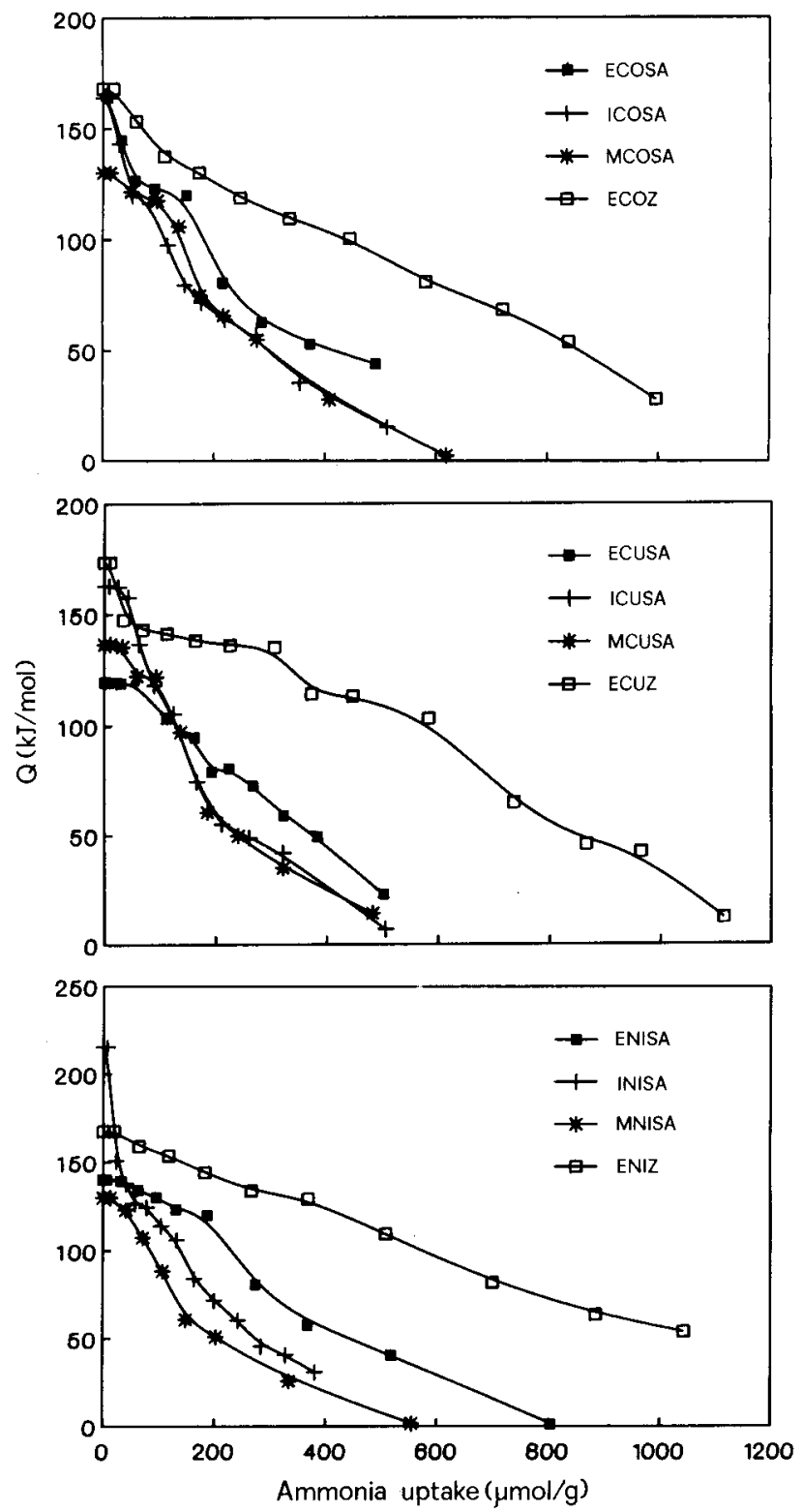

Figure 7. Differential heat of adsorption of $\mathrm{NH}_{3}$ over $\mathrm{Co}-, \mathrm{Cu}-$, and Ni-based samples on silica-alumina, SA, and ZSM-5, Z, supports.

the two cases. Previous studies ${ }^{30,83}$ have shown that, when $\mathrm{NH}_{3}$ is used as a basic probe to titrate the acid surface of catalysts, the $\mathrm{N} 1 \mathrm{~s}$ binding energy turns toward values higher than 402 $\mathrm{eV}$ for adsorption on a Brönsted site, but toward values lower than $401 \mathrm{eV}$ for adsorption on a Lewis acid site. All the experimental $\mathrm{N}$ 1s XPS peaks were found to be broad and nonsymmetric, strongly suggesting that the $\mathrm{N} 1 \mathrm{~s}$ peaks were composite peaks that had to be decomposed. The broadening of the $\mathrm{N}$ 1s peaks can be attributed to a distribution of acidity over a large range of acid strengths and to an adsorption on sites of different nature.

The N 1s XPS profiles have been decomposed into two components with binding energies at $400.4 \pm 0.5$ and 402.25 $\pm 0.45 \mathrm{eV}$. The significant differences in the spectra were the relative intensities of the two components. Figures 9-12 show the $\mathrm{N}$ 1s XPS experimental profiles of $\mathrm{NH}_{3}$ adsorbed on ZSM-5 and SA supports and on $\mathrm{Co}-, \mathrm{Cu}-$, and $\mathrm{Ni}$-containing samples prepared by the three procedures on the two supports. In the case of ZSM-5 zeolites, Borade et al. ${ }^{39}$ identifies three different types of acid sites (Lewis, weak and strong Brönsted sites) by chemisorption of pyridine. Indeed, they decomposed the $\mathrm{N} 1 \mathrm{~s}$

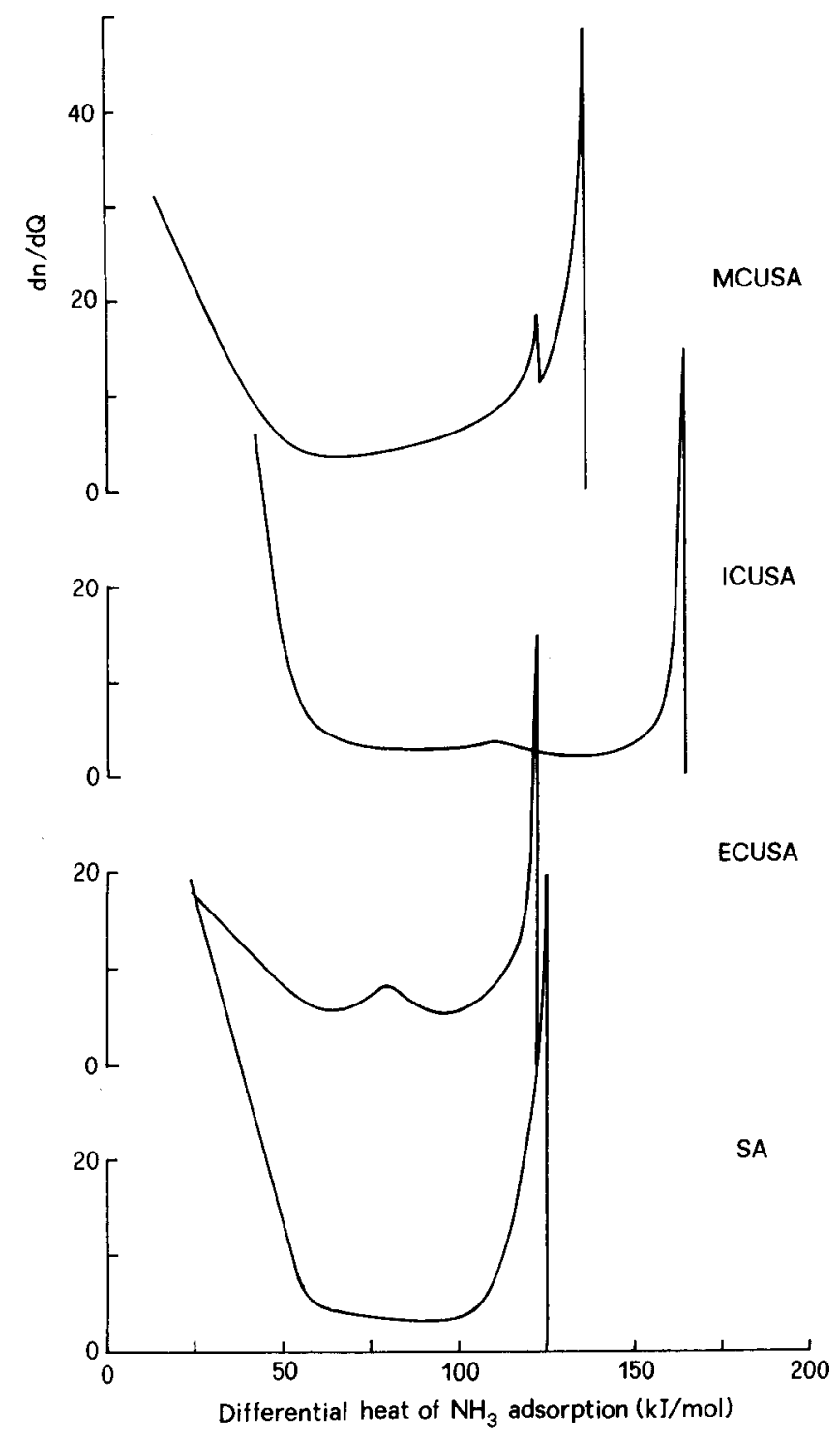

Figure 8. Acid site energy distribution for the $\mathrm{Cu}$-containing samples prepared by different procedures on silica-alumina.

TABLE 3: N 1s Binding Energies (BE) of the AmmoniaSaturated Samples and Related Proportions of Brönsted (B) and Lewis (L) Acid Sites

\begin{tabular}{lcccccc}
\hline & \multicolumn{2}{c}{ Brönsted site } & & \multicolumn{2}{c}{ Lewis site } & \\
\cline { 2 - 3 } sample & $\begin{array}{c}\text { BE N 1s } \\
(\mathrm{eV})\end{array}$ & $\begin{array}{c}\text { relative } \\
\text { intensity }(\%)\end{array}$ & $\begin{array}{c}\text { BE N 1s } \\
(\mathrm{eV})\end{array}$ & $\begin{array}{c}\text { relative } \\
\text { intensity }(\%)\end{array}$ & \\
\hline B/L $\mathrm{L}^{a}$ \\
\hline ECOZ & 401.8 & 30 & & 399.9 & 70 & 0.43 \\
ECOSA & 402.1 & 45 & & 400.5 & 55 & 0.82 \\
ICOSA & 402.2 & 50 & & 400.5 & 50 & 1.00 \\
MCOSA & 402.1 & 45 & & 400.3 & 55 & 0.82 \\
ECUZ & 402.2 & 15 & & 400.3 & 85 & 0.18 \\
ECUSA & 401.8 & 40 & & 400.3 & 60 & 0.67 \\
ICUSA & 402.1 & 60 & & 400.2 & 40 & 1.50 \\
MCUSA & 401.9 & 50 & & 400.0 & 50 & 1.00 \\
ENIZ & 402.7 & 10 & & 400.3 & 90 & 0.11 \\
ENISA & 402.3 & 30 & & 400.4 & 70 & 0.43 \\
INISA & 402.3 & 50 & & 400.6 & 50 & 1.00 \\
MNISA & 402.2 & 60 & & 400.4 & 40 & 1.50 \\
Z & 402.3 & 65 & & 400.5 & 35 & 1.86 \\
SA & 402.4 & 60 & & 400.9 & 40 & 1.50
\end{tabular}

${ }^{a}$ Relative concentration of Brönsted and Lewis acid sites estimated from the relative intensities of $\mathrm{N}$ 1s XPS bands.

XPS bands into three components. The width of our experimental $\mathrm{N} 1 \mathrm{~s}$ bands for ammonia chemisorbed allowed only a 
TABLE 4: Evaluation of the Number of Brönsted and Lewis Acid Sites from Microcalorimetric and XPS Results of $\mathrm{NH}_{3}$ Adsorption

\begin{tabular}{lccc}
\hline sample & $\begin{array}{c}\text { total acid sites (Virr })^{a} \\
\left(\mu \mathrm{mol}_{\mathrm{NH}_{3}} / \mathrm{g}\right)\end{array}$ & $\begin{array}{c}\text { Brönsted site }_{\left(\mu \mathrm{mol}_{\mathrm{NH}_{3}} / \mathrm{g}\right)} \\
\left(\mu \mathrm{mol}_{\mathrm{NH}_{3}} / \mathrm{g}\right)\end{array}$ & $\begin{array}{c}\text { Lewis site } \\
(\mu 2\end{array}$ \\
ECOZ & 456 & 316 \\
ECOSA & 205 & 92 & 113 \\
ICOSA & 203 & 101.5 & 101.5 \\
MCOSA & 208 & 94 & 114 \\
ECUZ & 691 & 104 & 587 \\
ECUSA & 275 & 110 & 165 \\
ICUSA & 184 & 110 & 74 \\
MCUSA & 222 & 111 & 111 \\
ENIZ & 587 & 59 & 528 \\
ENISA & 288 & 86 & 202 \\
INISA & 188 & 94 & 94 \\
MNISA & 130 & 78 & 52 \\
Z & 420 & 273 & 147 \\
SA & 143 & 86 & 57
\end{tabular}

${ }^{a}$ Evaluated by microcalorimetric experiments of $\mathrm{NH}_{3}$ adsorption from the difference between the primary and secondary adsorption (data determined at $27 \mathrm{~Pa}$ of $\mathrm{NH}_{3}$ pressure coverage).

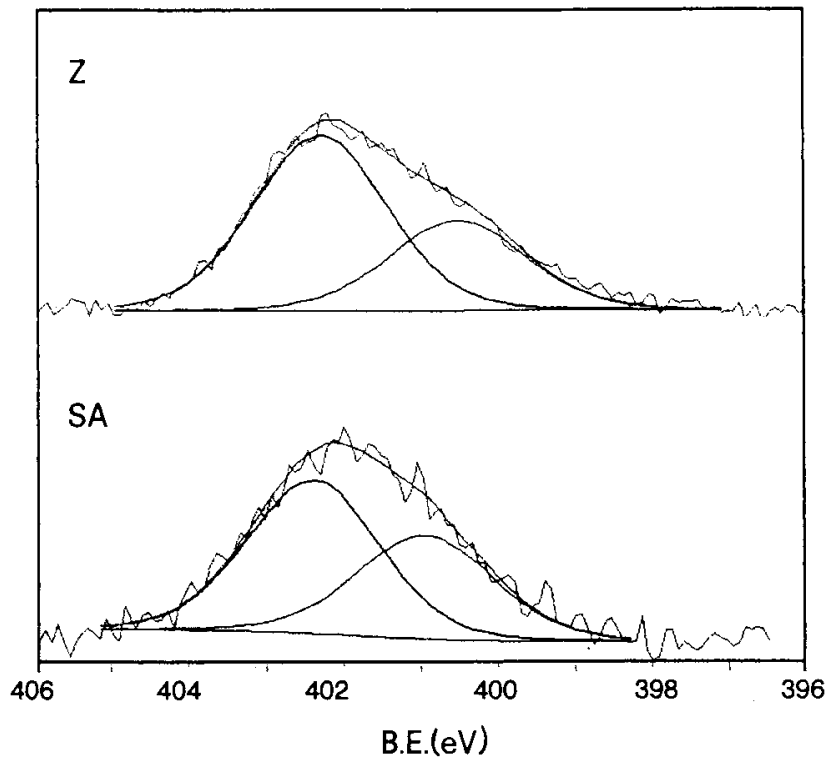

Figure 9. Experimental and decomposed $\mathrm{N}$ 1s $\mathrm{XP}$ spectra of chemisorbed $\mathrm{NH}_{3}$ on $\mathrm{ZSM}-5, \mathrm{Z}$, and silica-alumina, $\mathrm{SA}\left(\mathrm{NH}_{3}\right.$ exposure, $133 \mathrm{~Pa}$ at $\left.80{ }^{\circ} \mathrm{C}\right)$.

decomposition into two components as found in the case of HY zeolites. ${ }^{30,83}$ This apparent discrepancy could be coming from the nature of the basic probe molecule. Therefore, the $\mathrm{N} 1 \mathrm{~s}$ binding energy could be less sensible to the strength of Brönsted acid sites in the case of ammonia than in the case of pyridine.

As expected, silica-alumina and ZSM-5 had characteristics of protonic acids, with high amounts of Brönsted sites (60 and $65 \%$, respectively). The ratios of the amounts of Brönsted and Lewis ratios were 1.86 and 1.50 for $\mathrm{Z}$ and SA, respectively (Table 3 and Figure 9). The Lewis acid sites could correspond to $\mathrm{Al}$ atoms in an octahedral environment (extraframework $\mathrm{Al}$ ) as well as to trivalent $\mathrm{Al}$ atoms (crystal defects).

The presence of metal ions deposited on the two matrixes very deeply changed the proportions between Brönsted and Lewis sites, the latter being in large majority (Table 3). The Brönsted to Lewis site ratio was less than 1, except for ICUSA and MNISA samples on which the proportion between acid sites was not changed compared with the SA support. The increase of the Lewis site population is related with the surface concentration of the metal ions, which have strong interaction

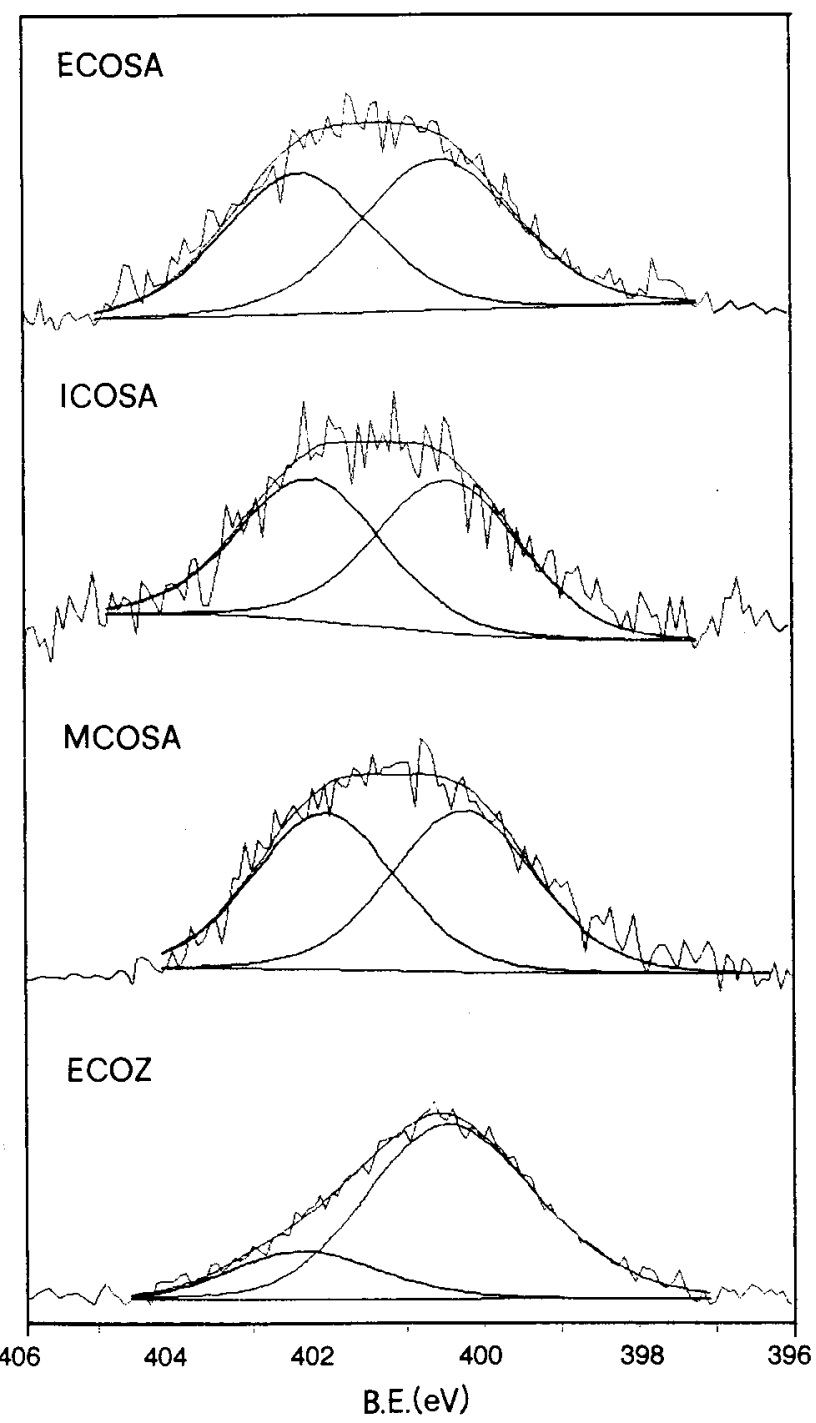

Figure 10. Experimental and decomposed $\mathrm{N}$ 1s XP spectra of chemisorbed $\mathrm{NH}_{3}$ on Co-based samples on silica-alumina, $\mathrm{SA}$, and ZSM-5, Z, supports.

with the support. The changing in the acid feature of the metal ion containing samples was particularly remarkable for the ZSM5-based catalysts (ECOZ, ECUZ, and ENIZ); the Lewis acid site population was between 70 and $90 \%$ with a Brönsted to Lewis site ratio between 43 and 0.11 . This behavior indicates the presence of acid metal centers with deficient charge density due to an electron transfer toward the support. Moreover, it is expected that the deposition of metal ions on both supports led to a decrease in the proportion of Brönsted to Lewis acid sites as well as in the number of Brönsted sites being engaged in the anchorage of the metal ions.

Once the total number of acid sites, from adsorption microcalorimetry, and the concentration of the different acid types (i.e., Brönsted and Lewis), from XPS, are known, it should be possible to determine the absolute number of Brönsted and Lewis sites on each sample. Table 4 has been compiled in an attempt at evaluating the amount of Brönsted and Lewis acid sites expressed in $\mu \mathrm{mol}_{\mathrm{NH}_{3}} / \mathrm{g}$ and assuming a 1:1 stoichiometry for $\mathrm{NH}_{3}$ adsorbed on surface acid sites. For the evaluation, Virr, which represents the amount of $\mathrm{NH}_{3}$ chemisorbed at low equilibrium pressure $(27 \mathrm{~Pa})$, was considered. Virr can be associated with the number of acid sites which strongly retained $\mathrm{NH}_{3}$, that is, sites with high acid strength. Moreover, the $\mathrm{N} \mathrm{1s}$ XPS peaks were related with $\mathrm{NH}_{3}$ retained on strong acid sites, 


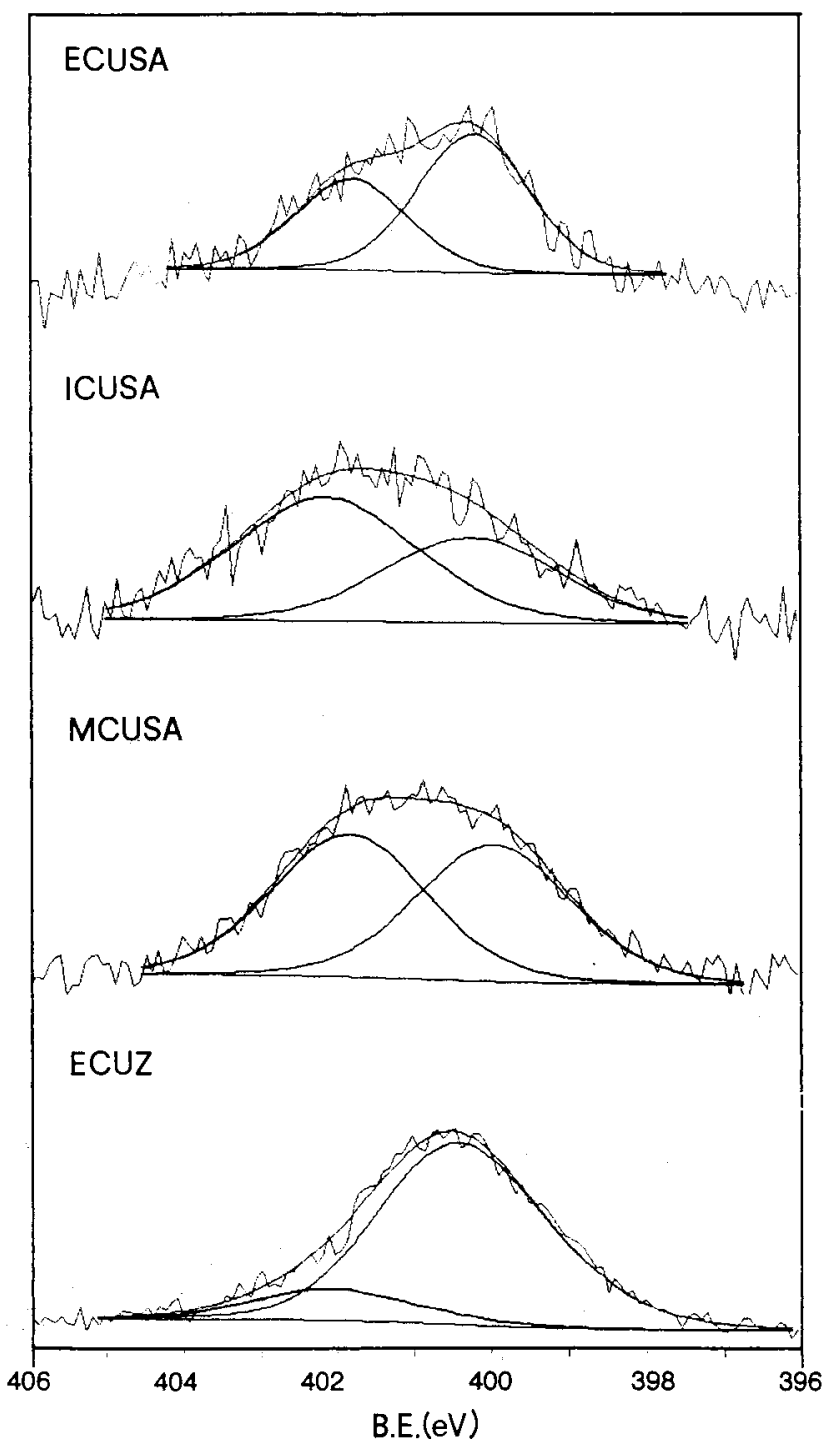

Figure 11. Experimental and decomposed N 1s XP spectra of chemisorbed $\mathrm{NH}_{3}$ on $\mathrm{Cu}$-based samples on silica-alumina, $\mathrm{SA}$, and ZSM-5, Z, supports.

since the physisorbed $\mathrm{NH}_{3}$ was pumped off before XPS investigation.

A clear increase of the acid character of the samples was observed following the deposition of the metal ions on both SA and Z (Table 4). The samples prepared on ZSM-5 (ECOZ, ECUZ, and ENIZ) had the highest amount of Lewis acid sites. Among the samples prepared on $\mathrm{SiO}_{2}-\mathrm{Al}_{2} \mathrm{O}_{3}$, the preparation by ion-exchange (E) led to the highest number of Lewis sites, a behavior which was observed for $\mathrm{Co}-, \mathrm{Cu}-$, and $\mathrm{Ni}$-containing samples. As regards the Brönsted acid sites, the samples prepared on SA had, on the average, the same number of sites as the amorphous matrix. The nature of the Brönsted sites of the metal ion samples and of those of the SA matrix are different, the first ones being associated with metal hydroxyls ( $\mathrm{Co}, \mathrm{Cu}$, and $\mathrm{Ni}$ metal hydroxyls) and the others with the hydroxyls of the $\mathrm{Al}$ and/or Si of the matrix. On the other hand, the samples prepared on ZSM-5 presented about half the number of Brönsted sites possessed by the ZSM-5 matrix.

\section{Conclusions}

A detailed characterization of the acid sites of differently prepared metal ion modified amorphous and crystalline silica-

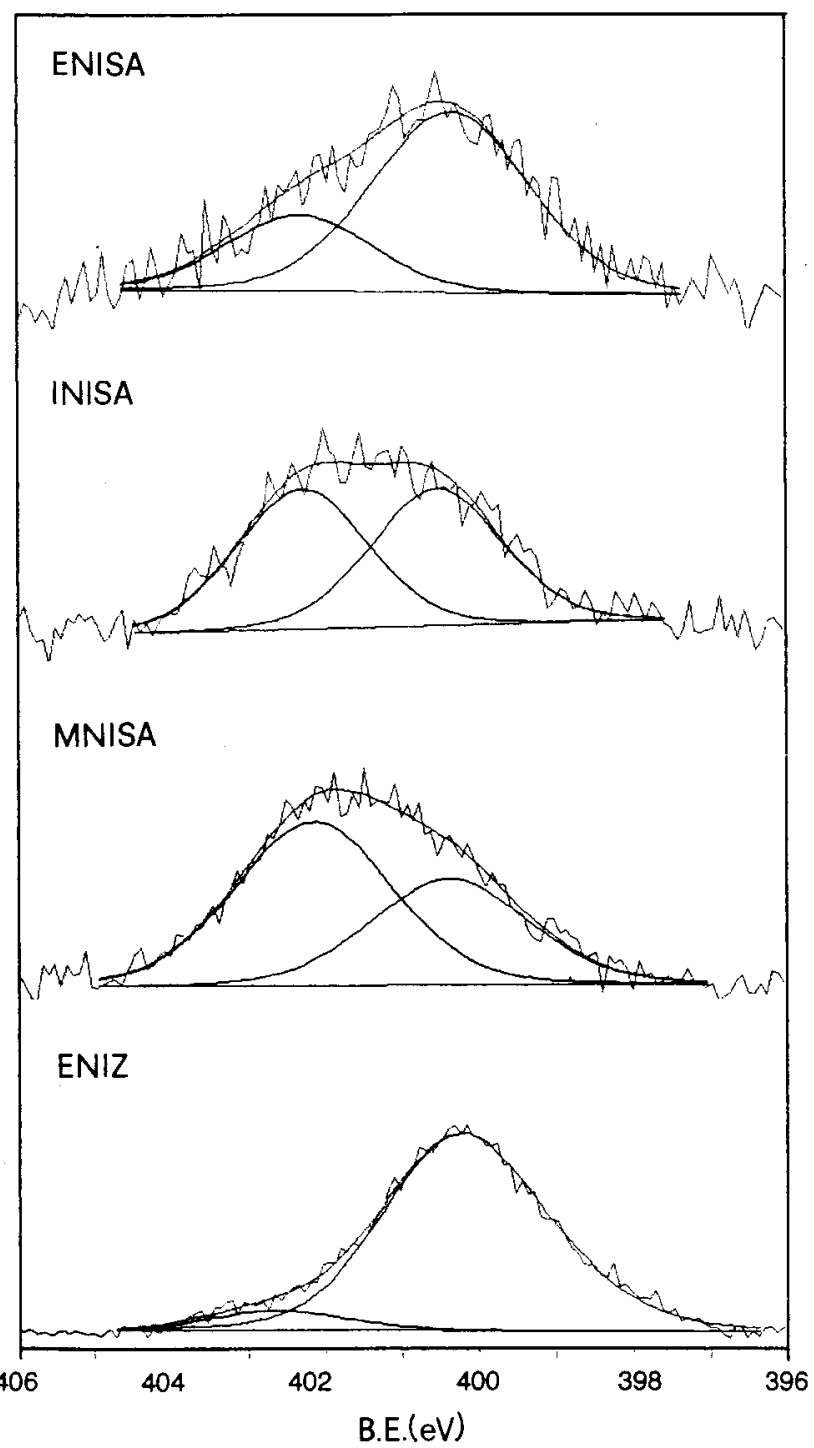

Figure 12. Experimental and decomposed N 1s XP spectra of chemisorbed $\mathrm{NH}_{3}$ on Ni-based samples on silica-alumina, $\mathrm{SA}$, and ZSM-5, Z, supports.

alumina samples $\left(\mathrm{Co}, \mathrm{Cu}\right.$, and $\mathrm{Ni}$ on $\mathrm{ZSM}-5$ and $\left.\mathrm{SiO}_{2}-\mathrm{Al}_{2} \mathrm{O}_{3}\right)$ was carried out using ammonia adsorption microcalorimetry and N 1s XP spectroscopy of ammonia adsorbed on the surfaces. The XPS results demonstrated that ammonia was chemisorbed in two main different states, namely on Lewis sites and Brönsted sites corresponding to a BE of, on the average, 400.4 and 402.2 $\mathrm{eV}$, respectively. The coupled approach of XPS and microcalorimetry has permitted the determination of the absolute number of Brönsted and Lewis acid sites on the various samples.

The two support matrixes, which are prevalently protonic acids, were changed into Lewis acid types by the deposition of the metal ions. In the case of the samples prepared by the ion exchange procedure, homogeneous surfaces have been observed, on which the metal ions were present in a unique oxidation state as isolated ions rather than as oxide clusters. The observed shift of the $2 \mathrm{p}^{3 / 2}$ bands of the metal ions toward high binding energies with respect to the values typical for bulk oxides indicated an active charge transfer from the metal ions to the support. The electron-deficient ions acted as Lewis acid sites. Besides well-dispersed metal ions, oxide clusters were formed by the impregnation and solid-state ion exchange procedures. 


\section{References and Notes} 169

(1) Zecchina, A.; Lamberti, C.; Bordiga, S. Catal. Today 1998, 41,

(2) Rabo, J. A. Zeolite Chemistry and Catalysis; ACS Monograph 171; American Chemical Society: Washington, DC, 1979; Chapter 8.

(3) Barthomeuf, D. Stud. Surf. Sci. Catal. 1980, 5, 55.

(4) Kijenski, J.; Baiker, A. Catal. Today 1989, 5, 1.

(5) Weitkamp, J. Stud. Surf. Sci. Catal. 1991, 65, 21.

(6) Tanabe, K.; Misono, M.; Ono, Y.; Hattori, H. Stud. Surf. Sci. Catal.

1989, 51,1

(7) Rabo, J. A.; Gajda, G. J. Catal. Rev. 1990, 31, 385.

(8) Corma, A. Chem. Rev. 1995, 95, 559

(9) Farneth, W. E.; Gorte, R. J. Chem. Rev. 1995, 95, 615

(10) Gorte, R. J.; White, D. Top. Catal. 1997, 4, 57.

(11) Demmin, R. A.; Gorte, R. J. J. Catal. 1984, 90, 32.

(12) Hunger, B.; Hoffman, J. Thermochim. Acta 1986, 106, 133

(13) Karge, H. G. In Catalysis and Adsorption by Zeolites; Ohlmann,

et al., Eds.; Elsevier: Amsterdam, 1991; p 133.

(14) Yori, J. C.; Luy, J. C.; Parera, J. M. Appl. Catal. 1988, 41, 1.

(15) Berteau, P.; Delmon, B. Catal. Today 1989, 5, 121.

(16) Karge, H. G.; Dondur, V. J. Phys. Chem. 1990, 94, 765.

(17) Forni, L.; Magni, E. J. Catal. 1988, 112, 437.

(18) Forni, L.; Magni, E.; Ortoleva, E.; Monaci, R.; Solinas, V. J. Catal.

1988, 112, 444

(19) Delgass, W. N.; Haller, G. L.; Kellerman, R.; Lunsford, J. H. Spectroscopy in Heterogeneous Catalysis; Academic Press: New York, 1979.

(20) Haller, G. T. Catal. Rev.-Sci. Eng. 1981, 477.

(21) Kung, M. C.; Kung, H. H. Catal. Rev.-Sci. Eng. 1985, 27, 425.

(22) Thomas, J. M. Faraday Discuss. 1996, 105, 1.

(23) Barzetti, T.; Selli, E.; Moscotti, D.; Forni, L. J. Chem. Soc., Faraday

Trans. 1996, 92, 1401.

(24) Kustov, L. M. Top. Catal. 1997, 4, 131. 047.

Knözinger, H.; Huber, S. J. Chem. Soc., Faraday Trans. 1998, 94

(26) Busca, G. Catal. Today 1998, 41, 191.

(27) Vedrine, J. C.; Auroux, A.; Bolis, V.; Dejaifve, P.; Naccache, C.; Wierzchowski, P.; Derouane, E. G.; Nagy, J. B.; Gilson, J.-P.; van Hooff, Jan H. C.; van den Berg, J. P.; Wolthuizen, J. J. Catal. 1979, 59, 248.

(28) Chen, D.; Sharma, S.; Cardona-Martínez, N.; Dumesic, J. A.; Bell,

V. A.; Hodge, G. D.; Madon, R. J. J. Catal. 1992, 136, 392.

(29) Mcqueen, D.; Chiche, B. H.; Fajula, F.; Auroux, A.; Guimon, C.; Fitoussi, F.; Schulz, P. J. Catal. 1996, 161, 587.

(30) (a) Boreave, A.; Auroux, A.; Guimon, C. Micropor. Mater. 1997,

11, 275. (b) Guimon, C.; Boreave, A.; Pfister-Guillouzo, G. Surf. Interface

Anal. 1994, 22, 407

(31) Auroux, A.; Datka, J. Appl. Catal. A 1997, 165, 473.

(32) Narayanan, S.; Sultana, A.; Le, Qt.; Auroux, A. Appl. Catal. A 1998, 168, 373.

(33) Natalsantiago, M. A.; Dumesic, J. A. J. Catal. 1998, 175, 252.

(34) Cardona-Martinez, N.; Dumesic, J. A. Adv. Catal. 1992, 38, 149.

(35) Auroux, A. In Physical Techniques for Solid Materials; Imelik,

B., Vedrine, J. C., Eds.; Plenum Press: New York, 1994; p 611.

(36) Andersen, P. J., Kung, H. H. Catalysis 1995, 11, 441

(37) Solinas, V.; Ferino, I. Catal. Today 1998, 41, 179.

(38) Defosse, C.; Canesson, P. J. Chem. Soc., Faraday Trans. 1976 $11,2565$.

(39) Borade, R.; Sayari, A.; Adnot, A.; Kaliaguine, S. J. Phys. Chem. 1990, 94, 5989.

(40) Borade, R.; Adnot, A.; Kaliaguine, S. J. Catal. 1990, 126, 26.

(41) Auroux, A. Stud. Surf. Sci. Catal. 1988, 37, 385.

(42) Kapustin, G. I.; Brueva, T. R.; Klyachko, A. L.; Beran, S.; Wichterlová, B. Appl. Catal. 1988, 42, 239.
(43) Lohse, U.; Parlitz, B.; Patzelová J. Phys. Chem. 1989, 93, 3677.

(44) Auroux, A.; Gervasini, A. J. Phys. Chem. 1990, 94, 6371.

(45) Cardona-Martinez, N.; Dumesic, J. A. J. Catal. 1990, 125, 427.

(46) Cardona-Martinez, N.; Dumesic, J. A. J. Catal. 1991, 127, 706.

(47) Cardona-Martinez, N.; Dumesic, J. A. J. Catal. 1991, 128, 23.

(48) Gervasini, A.; Auroux, A. J. Phys. Chem. 1993, 97, 2628.

(49) Parrillo, D. J.; Gorte, R. J. J. Phys. Chem. 1993, 97, 8786.

(50) Jozefowicz, L. C.; Karge, H. G.; Coker, E. N. J. Phys. Chem. 1994 98,8053

(51) Gervasini, A.; Bellussi, G.; Fenyvesi, J.; Auroux, A. J. Phys. Chem. 1995, 99, 5117 .

(52) Gervasini, A.; Fenyvesi, J.; Auroux, A. Langmuir 1996, 12, 5356

(53) Occelli, M. L.; Eckert, H.; Hudalla, C.; Auroux, A.; Ritz, P.; Iyer,

P. S. Micropor. Mater. 1997, 10, 123.

(54) Ducourty, B.; Occelli, M. L.; Auroux, A. Thermochim. Acta 1998 312,27

(55) Auroux, A. Top. Catal. 1997, 4, 71.

(56) Huang, M.; Adnot, A.; Kaliaguine, S. J. Chem. Soc., Faraday Trans. 1993, 89, 4231.

(57) Kaliaguine, S. Appl. Catal. B 1998, 15, 259

(58) Johansson, M.; Klier, K. Top. Catal. 1997, 4, 99.

(59) Masuda, T.; Taniguchi, H.; Tsutsumi, K.; Takahashi, H. Bull. Chem. Soc. Jpn. 1979, 52, 2849.

(60) Sachtler, W. M. H.; Zhang, Z. Adv. Catal. 1993, 39, 129.

(61) Shelef, M. Chem. Rev. 1995, 95, 209.

(62) Sato, S.; Yu-u, Y.; Yahiro, H.; Mizuno, N.; Iwamoto, M. Appl.

Catal. 1991, 70, L1.

(63) Li, Y.; Armor, J. N. Appl. Catal. B 1993, 3, 55.

(64) Burch, R.; Millington, P. J. Appl. Catal. B 1993, 2, 101. 68.

(66) Gervasini, A.; Ragaini, V.; Auroux, A. In Environmental Catalysis; Centi, G., et al., Eds.; EFC Publications (Series 112): Roma, 1995; p 279.

(67) Yamashita, T.; Vannice, A. J. Catal. 1996, 163, 158.

(68) Chen, H. Y.; Sachtler, W. M. H. Catal. Lett. 1998, 50, 125.

(69) Yamada, K.; Pophal, C.; Segawa, K. Micropor. Mesopor. Mater. 1998, 21, 549

(70) Kögel, M.; Sandoval, V. H.; Schwieger, W.; Tissler, A.; Turek, T. Catal. Lett. 1998, 51, 23.

(71) Shirley, D. A. Phys. Rev. B 1972, 5, 4709.

(72) Scofield, J. H. J. Elect. Spectrosc. Relat. Phenom. 1976, 8, 129. 477 .

(73) Schwarz, J. A.; Contescu, C.; Contescu, A. Chem. Rev. 1995, 95 ,

(74) Carniti, P.; Gervasini, A.; Ragaini, V. J. Chem. Soc., Faraday Trans. 1997, 93, 1641

(75) Gervasini, A. Appl. Catal. A 1999, 71, 180

(76) Handbook of XPS; Wagner, C. D., et al., Eds.; Perkin-Elmer Corp.: Eden Prairie, 1979

(77) Seah, M. P.; Surf. Interface Anal. 1986, 9, 85.

(78) Carniti, P.; Gervasini, A.; Auroux, A. J. Catal. 1994, 150, 274.

(79) Tsyganenko, A. A.; Podzdnyakov, D. V.; Filimonov, V. N. J. Mol. Struct. 1975, 29, 299.

(80) Haase, F.; Sauer, J. J. Phys. Chem. 1994, 98, 3083.

(81) Remy, M. J.; Genet, M. J.; Lardinois, P. F.; Notte, P. P.; Poncelet, G. Surf. Interface Anal. 1994, 21, 643.

(82) Borade, R. B.; Clearfield, A. J. Chem. Soc., Faraday Trans. 1995, 91,539 .

(83) Guimon, C.; Zouiten, A.; Boreave, A.; Pfister-Guillouzo, G.; Schultz, P.; Fitoussi, F.; Quet, C. J. Chem. Soc., Faraday Trans. 1990, 90, 3461. 